\title{
ACCOUNTING IMPLICATIONS OF FOREIGN CURRENCY TRANSACTIONS TRANSLATION AND HEDGING
}

\author{
Jasmina Bogicevic* \\ Faculty of Economics, University of Kragujevac, Kragujevac, Serbia
}

Due to the internationalization of business and frequent fluctuations in exchange rates, information about the impact of changes in exchange rates on individual companies' and multinational groups' financial position and profitability has become increasingly important. Data on the translation effects of both foreign currency transactions and foreign subsidiaries' financial statements, a company's exposure to different types of foreign exchange risks and taken currency hedging measures enable many users of accounting contents to obtain a better picture of an entity's financial position and its profitability. The key issues relate to the choice of the exchange rate to be used in accounting data translation and the financial reporting presentation of translation effects. While the effects of the foreign subsidiaries' financial statements translation can be shown in the balance sheet and the income statement, the effects of foreign currency transactions translation are incorporated in the income statement. This paper discusses the accounting aspects of the foreign currency transactions translation, an enterprise's transactional exposure to a currency risk, and the use of financial derivative instruments to hedge against foreign exchange risk.

Keywords: foreign currency transaction, transaction exposure, foreign currency financial statements, currency hedging

\section{JEL Classification: M41, F3}

\section{INTRODUCTION}

The complex field of international accounting could be perceived in the easiest way on the basis of its descriptive/comparative and pragmatic domains. While the descriptive/comparative aspects of international accounting are primarily focused on the research and classification of national accounting systems,

\footnotetext{
* Correspondence to: J. Bogicevic, Faculty of Economics, University of Kragujevac, Dj. Pucara 3, 34000 Kragujevac, Serbia; e-mail: jasminab@kg.ac.rs
}

the pragmatic domains are related to the accounting dimension of international transactions and activities of multinational enterprises/MNEs (Radebaugh \& Gray, 1997, 11) The key international accounting pragmatic aspects are related to the consolidation, segmental reporting, foreign currency translation and foreign currency hedging. The importance of studying the two latter interactive international accounting areas has particularly been evident in the recent years due to the expansion of international business, financial and investment activities, and the expressed flexibility in exchange rates. 
In an accounting context, foreign currency translation is the restatement of accounting data expressed in one currency into another. The necessity of foreign currency accounting contents translation is particularly evident in the recording of foreign currency transactions in the books of accounts and the preparation of an individual company's financial statements as well as the consolidation of foreign subsidiaries' financial statements with their parent company's financial statements on condition that they are not expressed in a common currency (Nobes \& Parker, 2010). Due to the impact of fluctuations in exchange rates on foreign currency transactions, enterprises face transaction exposure to exchange-rate risk, which directly effects their cash flows and profitability when they are settling a monetary transaction. In order to hedge against transaction exposure to foreign exchange risk, companies mainly enter into financial currency hedging arrangements. This type of hedging connects gains and losses on foreign currency financial derivatives (hedging instruments) with losses or gains on items that are the subject of currency hedging.

Therefore, the subject of this research paper will be focused on the analysis of the interaction of foreign currency accounting contents translation and a company's exposure to various types of foreign exchange risk. More specifically, the study focuses on the analysis of the accounting aspects of foreign currency transaction translation and their currency risk hedging in terms of fluctuations in exchange rates. Starting from a very high level achieved not only de jure but also de facto of international accounting harmonization in these areas, the international convergence of foreign currency translation accounting regulations and its repercussions for our country are imposed as a particularly important aspect of the research.

Having in mind the previously defined and explained research subject, the main goal of the paper, based on the consideration of the conceptual issues of transaction translation and transaction exposure to foreign exchange risk, is to point out their interaction with currency hedging as well as to interpret those causal relationships in the accounting context. The significant research objectives are reflected in the assessment of the effects of foreign currency transactions translation and currency hedging on a company's financial position and its profitability, as well as in the analysis of the existing practices of accounting for the effects of changes in exchange rates in representative enterprises in the Republic of Serbia (RS).

According to the subject exposed and the research objectives set, the following hypothesis will be tested in the paper: There is a statistically significant correlation between the level of an enterprise's transaction exposure to foreign exchange risk and the level of currency hedging application.

Having defined the problem, the subject and the research objectives, and having set the research hypotheses, we have provided a detailed presentation of the literature on foreign currency accounting. Understanding these complex theoretical and methodological aspects enables us to become familiar with the practical cases of both foreign individual and multinational enterprises (MNEs) as well as to have them compared with the practice of local entities. This survey of representative enterprises in our country, which are faced with foreign currency transactions and currency hedging, makes it possible to generate some relevant empirical findings on the key issues of foreign currency accounting contents translation and the possibilities of the implementation of international achievements in having them resolved. In the research process, a wide range of methodological procedures and techniques allowing the verification of the hypotheses are used. Finally, the main results of the theoretical and empirical research into the accounting implications of foreign currency translation and currency hedging will be the understanding of interactivity in these areas, the promotion of the international convergence of foreign currency accounting regulations and the analytical interpretation of the effects of application of different foreign currency transaction translation methods on a company's financial position and yield.

In accordance with the determined objectives, the goals and the initial hypothesis, and after considering the accounting aspects of foreign currency translation, accounting for transactions in foreign currency will be discussed in the paper. Then, an enterprise's transaction exposure to foreign currency risk will 
be discussed, followed by the consideration of the exposure of an enterprise's transaction to foreign currency risk. The last part of the paper will focus on the financial hedging of foreign currency transactions. In addition, instead of the initial integrative review of the previous research, a sequential review of the literature will be used in each part of the paper.

\section{THE ACCOUNTING ASPECTS OF FOREIGN CURRENCY TRANSLATION}

The specific meaning of the foreign currency translation syntagm is emphasized in the economic literature. In the accounting context, foreign currency translation is a process of expressing financial data presented in one currency into another one using appropriate exchange rates. Additionally, historical, current or average rates can be used in the process of the monetary expression of the change in the foreigncurrency denominated amount against the domestic currency equivalent.

While conversion implies a real, physical exchange of one currency for another, accountants use foreign currency translation in order to fulfill the condition of financial data currency homogeneity. As Englishspeaking accountants have taken this term from linguists, the term translation is incorrectly interpreted and used by non-accountants. (Nobes \& Parker, 2010, 412).

Generally, the reasons for translating foreigncurrency denominated financial data should be viewed in the context of the expansion of international business, financial and investment activities, an increase in the number of multinational groups, the frequency of fluctuations in exchange rates and the growing importance of financial reporting on the transparency of the inter-currency fluctuations effects on a company's financial position and profitability. Adequately translated financial data not only eliminate the information asymmetry between domestic and foreign users of accounting contents, but they are also a conditio sine qua non for the international group financial statements consolidation and segment reporting. In a number of situations, the necessity for accounting data translation arises both at the level of individual firms and the level of international groups. The problem of foreign currency transactions translation occurs in recording them in the book of accounts and in the preparation of financial statements of individual companies. The importance of translation, as a process of reformulating the information content of financial statements denominated in one currency into another, becomes particularly apparent in preparing MNEs' consolidated financial statements. There are other reasons causing a need for foreign currency translation, among which reporting on the results of independent activities abroad, reporting on the international activities of foreign subsidiaries and branches as well as their managers are emphasized.

Although at first glance the importance of the foreign currency translation issue has declined in the Euro zone due to the demonetization of the national currencies of the majority of the European Union member states, the undeniable significance of this accounting area could undoubtedly be confirmed by the following arguments:

- The Member States of the European Union, alongside intergroup economic communications taking place in a single currency, continue to perform their business, financial and investment activities outside the Euro zone;

- As some countries (e.g. the United Kingdom, Denmark and those to have recently acquired the status of a European Union member state) have not carried out the demonetization of their national currencies in the Euro, there is still currency heterogeneity in the European Union; moreover, the intergroup economic relations between all the member states are not performed on the basis of a single currency; in other words, the EU is characterized by a multicurrency environment.

An illustrative explanation of the undisputed importance of foreign currency translation clearly reveals the generally accepted F. Choi's assertion, which says "foreign currency translation choices are at the core of the fundamental concepts underlying the present financial reporting" (Choi, 1997, 13.2). The leading authors in the international accounting area 
highlight the fact that foreign currency translation and corresponding currency hedging are the most complex and the most controversial aspects of international financial reporting. A number of studies dedicated to the exploration of the relative importance of specific problems in the international accounting area have been pointing out their priority for a long time. In this regard, the author H. P. Troberg $(1987,318)$ gives a numeric argument of this statement, noting that "of the top ten individual problems of the 88 ones evaluated by international accounting experts, there are five related to currency translation". T. Doupnik and H. Perera (2007, VI) cite the results of the two different surveys conducted by business executives indicating that the most important topics to be considered in an international accounting course are those related to foreign currency accounting.

The relevant literature points out that there is a problem in understanding foreign currency translation because of frequent fluctuations in exchange rates, which increase the number of exchange rates used in the translation process. The argumentation for this assertion is metaphorically confirmed by F. Choi and G. Meek $(2008,204)$, who notes that "if foreign exchange rates were relatively stable, the currency translation process would be no more difficult than translating inches and feet into their metric equivalents."

Faced with a lack of fixed exchange rates, accountants deal with two issues:

- Which type of exchange rate (historical or current) should be used to translate assets and liabilities denominated in a foreign currency?

- How should gains or losses arising from changes in exchange rates be treated in the accounting context?

As the applied exchange rate determines the value of the assets and liabilities of a company and influences its result, the first question should be paid maximum attention to. Another problem is related to the presentation, i.e. descriptive determination and financial reporting on the positioning of the translation effects, or as Flower (Nobes \& Parker, 2010, 415) qualifies it as translation differences. The financial statement disposition of these translation differences affects many important financial indicators, such as net income, total assets, equity, debt ratio, return on equity, etc.

The accounting aspects of foreign currency translation involve the processing of the following key issues, namely:

\section{- Foreign currency transaction translation and}

- Foreign currency financial statements translation.

Although the issues relating to the treatment of foreign currency transactions and their currency hedging are methodologically complex, they are mainly uniformly interpreted in the relevant accounting literature. When the translation of foreign subsidiaries' financial statements denominated in a foreign currency are concerned, there are a number of controversies, mainly arising from different interpretations of the following conceptual issues: (a) the choice of exchange rates to restate amounts denominated in one currency into another, and (b) financial reporting on the positioning of translation effects. Depending on the exchange rates applied in the translation of financial statements of foreign subsidiaries into a single currency equivalent, a number of methods are differentiated, such as the current rate method, the current/non-current method, the monetary/ nonmonetary method and the temporal method. Using different methods of financial statements translation has resulted in a wide range of translation results, different amounts of net assets as well as different translation exposures to foreign exchange risk.

Given the thematic orientation of this paper, the accounting implications of foreign currency transactions translation and a consecutive transaction exposure to foreign exchange risk are predominantly important to further be considered. Pursuing a holistic consideration of the relevant accounting implications of the effects of changes in exchange rates on foreign currency transactions, the key aspects of transaction exposure hedging will be considered. A focus on transaction exposure does not mean that the presence of the other types of foreign exchange risk should be sidelined. Simply, a detailed consideration of them is beyond the scope of this paper. 


\section{ACCOUNTING TREATMENT OF FOREIGN CURRENCY TRANSACTIONS}

Accountants are faced with the problem of foreign currency transactions translation in the context of their recording in the books of accounts as well as in preparing a set of financial statements at the level of individual companies. In fact, it is those transactions that involve a settlement, i.e. debt collection or the payment of liabilities in a foreign currency. In addition to this, it is necessary that a strict distinction should be made between transactions in a foreign currency, on the one hand, and foreign trade, i.e. import-export transactions, on the other. Actually, in any international transaction, there is only one party to be faced with the problem of accounting for them in a foreign currency because a payment is usually specified in a single currency. Consequently, only the party who is settling a liability or a receivable in a currency other than its national currency faces foreign currency transactions. Beside sales activities, transactions in foreign currencies mainly include borrowing or lending money as well as a dividend payment (Roberts et al, 2008, 181). R. Baker et al. (2005, 542), similarly specified transactions in foreign currency:

- "Purchases or sales of goods or services (imports or exports), the prices of which are stated in foreign currencies;

- Loans payable or receivable in a foreign currency;

- A purchase or sale of foreign currency forward exchange contracts;

- A purchase or sale of foreign currency units."

Accountants have assumed a unique attitude that the initial bookkeeping records of foreign currency transactions should be based on an effective exchange rate on the transaction date. Because of a potential utilization of a credit conditions during exchange-rate fluctuations, the unrealized part of the transaction, (the outstanding obligation and/or outstanding receivables in a foreign currency) should be adjusted in the balance sheet at a date before the payment date. However, if an amount of a settled transaction is different from a previously recorded one, accountants are faced with the problem of the treatment of the identified difference, i.e. gains and losses on foreign currency transactions. In this regard, the two aspects were differentiated, namely: a single-transaction perspective and a two transaction perspective (Choi \& Meek, 2008, 209).

According to the first view, the real and the monetary part of a foreign currency transaction are treated as parts of a single business event. The liability payment or accounts receivable collection in foreign currencies are considered to be an indispensable and inseparable part of a purchase or sale transaction, respectively. According to the single-transaction perspective, the effect of changes in foreign exchange rates at selling goods on credit to foreign customers are recorded on foreign currency accounts receivable and sales revenue. As the Sales account is closed at the end of the prior period, the negative effects of the changes in foreign exchange at the beginning of the period are included in the Retained earnings account. Therefore, this perspective could be remarked as to the effects of changes in exchange rates being masked by adjusting the Sales account, or the Retained earnings in respect of credit payment terms.

According to the other view, foreign currency transactions are decomposed into a real and monetary segment, and a purchase or sale of goods, on the one hand, and the settlement of the obligation or the collection of a receivable, on the other, are separately treated. In other words, according to this perspective, exports and the correspondent collection are treated as two separate transactions. Since the management make two decisions on the sale of a product in an international market and also offer credit terms of payment to a foreign buyer, the effects of both of these decisions are stated separately in the income statement. The difference between the amount initially recorded on the transaction date and the amount by which the same is finally regulated (settled) is treated as a gain or a loss on a foreign currency transaction (transaction gains or losses). In other words, according to this view, initially recorded sales are not adjusted, but the effects of changes in exchange rates on foreign currency receivables are reported on as foreign exchange gains or losses.

Comparing these perspectives, it could be concluded that they both have an influence on a company's 
profitability in the same way. These perspectives differ in that, under the single transaction perspective, the amount of sales is adjusted for changes in exchange rates, and the effects of the more transparent of the two transaction perspectives are included in an exchange loss or gain.

While considering the effects of fluctuations in exchange rates in the context of the accounting treatment of foreign currency transactions, it is important to deal with the problem of the lack of a single, standardized method of the translation of the monetary part of a foreign currency transaction. In this regard, accountants have taken the view that the translation of the real part of a foreign currency transaction should be based on historical, i.e. transaction rates. On the contrary, there are three modalities of translation pointed out for the translation of monetary assets (receivables) and liabilities denominated in foreign currencies by Flower (Nobes \& Parker, 2010, 417):

"(1) at the historical rate. With this method, the home currency amount of these items is left unchanged and no translation gain or loss is reported.

(2) at the closing rate. Translation at the balance sheet rate gives the current value of these items in terms of the home currency, i.e. the amount of money that would be received on the balance sheet date if the monetary asset were converted into the home currency (mutatis mutandis for liabilities). When the closing rate is different from the historical rate, a translation difference arises, which is generally taken as a gain or a loss in the income statement;

(3) at the lower (higher) value of the historical rate and the closing rate for assets (liabilities). When this method is used, assets are stated at the lower of two possible values and liabilities at the higher one. The closing rate is only used if it gives rise to a loss on translation, which is charged to the income statement."

Since the first method can lead to an overestimation of monetary assets and an understatement of liabilities to their current values, it can be concluded that it is in direct contradiction to the principle of prudence. Therefore, the question of the argumentation and validity of such an approach is rightfully raised. Unlike this method, in the accounting literature, we can find well-founded arguments emphasizing the application of the second and third approaches.

According to the translation effects of the monetary part of foreign currency transactions (transaction gains and losses), the second method, which is based on the accrual principle, should be assigned to the accounting period in which a change in an exchange rate occurs rather than the period of cash and its equivalents collection or payment.

Both the regulatory authorities in the U.S. and the UK and those in other countries with the AngloSaxon style of accounting assume the attitude to the accounting allocation of gains or losses on foreign currency transactions translation since these translation differences are due to changes in exchange rates, which have just occurred during that accounting interval. Thus, both American Statement No. 52, Foreign Currency Translation (published in 1981), which is marked as ASC 830, officially became part of the Accounting Standards Codification by the decision reached by the Financial Accounting Standard Board - FASB (September 2009) and, under the same name, British Statement 20 generally follows the method based on the accrual principle. A similar approach is represented in the International Accounting Standard 21 (IAS 21), Accounting for the Effects of Changes in Foreign Exchange Rates.

The third method is based on the principle of prudence. In the context of foreign currency transactions, this principle is effected by the restatement of monetary assets and liabilities at the historical or the current exchange rate resulting in a lower value of assets and a higher value of liabilities. Because of a possibility of exchange rates moving in the opposite direction in the future, which may neutralize the positive effects of the current period, "cautious (prudent)" accountants are not ready to show gains on the translation of the monetary part transaction in the current period, but rather have them disposed in the period in which foreign currency receivables or liabilities will undoubtedly be settled.

Unlike the majority of the EU countries whose national policies advocate the application of the current rate in 
the translation of monetary assets, a more conservative approach is favored in Germany and France, which translates monetary assets at a lower historical or the current exchange rate while foreign currency liabilities are translated at a higher historical or the current exchange rate. Therefore, it is evident that this method can be used in those countries that favor or, better said give priority to the principle of prudence (Germany and France).

Summarizing the discussion on the pragmatic value of these methods, Flower (Nobes \& Parker, 2010, 419) notes that the best solution is the one based on a compromising treatment of both methods and states that "monetary assets and liabilities should be valued at the closing rate, whereas the transfer of a gain to the income statement should be deferred until the foreign currency asset/liability has been realized."

On the basis of an original empirical research conducted in 2010, while performing doctoral dissertation work, the accounting implications of foreign currency transactions translation as well as the analysis of the applied, existing, practice of currency risk management in representative enterprises in RS were assessed.

Beside the problem of the accounting treatment of foreign currency transactions, comments on the current accounting regulations in the field of international business were investigated, with a special emphasis on the consistency of the application of IAS 21.

In accounting for foreign currency transactions in Serbian enterprises, the majority of the surveyed respondents pointed out the problem of their inconsistent financial reporting presentation after the publication of the Ordinance on Changes and Amendments of the Regulation of the Chart of Accounts and Content of Accounts for Companies, Cooperatives, Legal Entities and Entrepreneurs ("The Official Gazette of RS", No. 9/2009). In fact, due to a large amount of the stated (recorded) foreign exchange losses to be reported as an expense in the income statement of companies in RS, by allowing their transfer to accruals, the Regulation has enabled the reposition of the effects of changes in exchange rates from the income statement to the balance sheet. Not only has it challenged the periodical comparability of a company's financial position and its profitability but it has also challenged the application of the part of the IAS 21 related to foreign currency transactions.

Accruals of the effects of exchange rate differences have for many years affected the financial position and profitability of a large number of companies in RS. We should keep it in mind that the transfer of the effects of deferred foreign exchange differences to the income and expenses of the accounting period will affect the financial statements in the years to come.

\section{COMPANY'S TRANSACTION EXPOSURE TO FOREIGN EXCHANGE RISK}

The internationalization of the economic activity associated with rising cross-currency instability directs a globally-oriented company to a higher perception of the exposure to foreign exchange risk and currency hedging. As S. Saudagaran $(2004,59)$ emphasized the fact that an exposure to foreign currency risk is a "measure of the potential of a firm's profitability, its cash flow and market value to change due to a change in exchange rates." In addition to this, the general concept of exposure to foreign exchange risk is not considered as monolithic in the literature, but is rather decomposed into the transaction, translation and economic segments (Demirag \& Goddard, 1994: Dhanani, 2003; Menon \& Viswanathan, 2005; Kim \& Kim, 2006; Madura \& Fox, 2011). A. Shapiro (2006) classifies foreign currency exposures into the transaction, operation and translation components. In this case, it is an economic exposure in a broader sense including the transaction and operating components. Although these alternative types of exposure reflect foreign exchange risk from various perspectives, with a considerable degree of congruency between them, it is necessary that they be identified separately. Not only do these types of exposure to foreign exchange risk affect the existing and prospective company's financial position and its profitability in a different way but they also entail the use of different hedging strategies.

The essential determinants of the transaction, translation and operating exposure are illustrated in Table 1. On that basis, and because of an overlap 
between these types of exposure to foreign exchange risk, it can be said not to draw a clear demarcation line between them.

Due to the impact of fluctuations in exchange rates on foreign currency transactions, enterprises are facing transaction exposure to exchange-rate risk, which, upon the regulation (settlement) of these transactions' monetary part, effected directly to both flows cash and profitability. Since these transactions result in a future foreign-currency cash inflows and outflows, changes in exchange rates from the period of their initial recording to the period of their settlement will cause a change in the amount of the inflow or outflow of local-currency cash. Transaction exposure refers to a potential change in the value of the outstanding receivables and payables stated in a foreign currency due to a possibility of exchange rate fluctuations during the period from contract signing to its completion. As the short-term component of economic exposure in the broadest sense, transaction exposure arises from a wide range of transactions exclusively settled in a foreign currency. This type of foreign currency risk exposure is present when the cash flows of certain foreign currency transactions are affected by changes in exchange rates and it "stems from an unprotected cash flow" (Nobes \& Parker, 2010, 571).

Although it was pointed out that transaction exposure is part of economic exposure in a broader sense, it is usually "lumped in together" with translation exposure. "In reality, transaction exposure overlaps with both accounting and operating exposures" (Shapiro, 2006, 338). The individual components of transaction exposures (assets and liabilities denominated in a foreign currency) for their inclusion in the balance sheet are also the segment of translation exposure. On the other hand, some elements of transaction exposure, such as, for example, forecasted foreign currency purchase/sales contracts are not a balance sheet item. Consequently, they are not part of the company's translation but an operating exposure.

Upon the collection of foreign currency receivables, the amount received and converted into a local currency would be reduced in the case of foreign currency devaluation. If receivables exposed to foreign exchange risk exceed exposed liabilities, foreign currency depreciation would lead to negative and the

Table 1 The comparison of the translation, transaction and operating exposures

\begin{abstract}
Translation exposure
Changes in income statement items and the book caused by an exchange rate change. The resulting exchange gains and losses are determined by accounting rules and are paper only. The measurement of accounting exposure is retrospective in nature and is based on activities that occurred in the past.

Impacts: postojeće pozicije bilansa stanja i bilansa uspeha.
\end{abstract}

\begin{abstract}
Operating exposure
Changes in the amount of future operating value of the balance sheet assets and liabilities cash flows by an exchange rate change. The resulting exchange gains and losses are determined by changes in the firm's future competitive position and are real. The measurement of operating exposure is prospective in nature as it is based on on future activities.

Impacts: prihode i rashode u vezi sa budućim prodajama.
\end{abstract}

EXCHANGE RATE CHANGE COURSE

Impacts: Contracts already entered into to be settled at a later date

\section{Transaction exposure}

Changes in the value of outstanding foreign-currency-denominated contracts (i.e. contracts that give rise to future foreign currency cash flows) brought about by an exchange-rate change. The resulting exchange gains and losses are determined by the nature of the contracts already entered into and are real. The measurement of transaction exposure mixes the retrospective and prospective ones because it is based on activities that occurred in the past but will be settled in the future. Contracts already in the balance sheet are part of accounting exposure, whereas contracts not yet in the balance sheet are part of operating exposure.

Source: Shapiro, 2006, 328 
appreciation of the exchange rate would lead to foreign exchange gains. On the other hand, if the amount of exposed foreign currency liabilities exceeds the amount of receivables, the depreciation of a foreign currency would result in foreign exchange gains. In contrast, the appreciation of the exchange rate would produce a difference. I. Demirag and S. Goddard (1994, 95) decompose transactional exposure into closed and open. While closed transaction exposure is associated with the already completed foreign currency transactions at the exchange rate different from the rate used in the initial valuation of foreign receivables or foreign obligations, open exposure is related to other outstanding foreign currency transactions.

Dynamically speaking, transaction exposure can be divided into (Saudagaran 2004, 60):

- "Quotation exposure, from the time the seller quotes a price to the time when the buyer orders the goods;

- Backlog exposure, from the moment an order is placed to the point of shipment (and invoicing);

- Billing exposure, referring to a lag between the point of shipping to the payment of the invoice."

Although all of these components of transaction exposure could be quantified, only the measure mentioned the last, i.e. the degree of billing exposure to foreign currency risk, is relevant for financial reporting.

The importance of identifying a degree of transaction exposure arises from the fact that it is an objectively conditioned exposure to foreign currency risk due to unregulated foreign receivables and/ or foreign liabilities that have already been established, and will be settled after a change in exchange rates. Numerous empirical studies confirm the highest relative importance of transaction exposure to foreign exchange risk, both in terms of attention given to this type of exposure in practice and in terms of financial managers' hedging preferences. A survey of 125 U.S. multinational companies, conducted by Malindretos and Tsanacas (according to Kim \& Kim $2006,236)$, disclosed that almost $2 / 3$ of the surveyed financial managers rank transaction exposure as the most important. 26 percent of the surveyed financial managers consider economic exposure as the most important. A survey revealed that only 13 percent of the respondents consider translation exposure as the most important type of exposure. The review has also concluded 65 percent of the companies' hedge transactions are exposed to foreign exchange risk, while only 26 percent of the financial managers from the observed sample implemented translation exposure hedging currency risk. The interviewed managers pay little attention from translation and operating exposure to foreign exchange risk because they believe that these types are not important and have no relevance that belongs to the transaction type of exposure. The relative importance of different types of foreign exchange exposure is shown in Table 2.

Table 2 The relative importance of different types of foreign exchange exposure

\begin{tabular}{lcc}
\hline Type of exposure & $\begin{array}{c}\text { Most impor- } \\
\text { tant exposure }\end{array}$ & $\begin{array}{c}\text { Hedging } \\
\text { preference }\end{array}$ \\
\hline Translation exposure & $13 \%$ & $26 \%$ \\
Transaction exposure & $64 \%$ & $65 \%$ \\
Economic exposure & $26 \%$ & $39 \%$ \\
\hline
\end{tabular}

Source: Kim \& Kim, 2006, 236

For the purpose of the research, the intensity of use and changes in the application of certain types of currency exposure hedging in Serbia, the author addressed the questionnaire to over 60 companies (Bogićević, 2011, 278-303). The questionnaire was answered by 35 enterprises, and more than 15 companies excused themselves for their inability to respond to the questions due to the problems of their insufficient knowledge. From the aspect of the activity, 19 of the surveyed units (i.e. $54.29 \%$ ) are industrial enterprises, and the 16 of them (i.e. $45.71 \%$ ) belong to the trading enterprises category. The twenty-five respondents are part of the group which consolidated financial statements are made for. Financial institutions are not included in the research, but exclusively companies. The respondents were asked to indicate the intensity of the use of certain types of currency risk hedging, where some replies were offered, such as "no use", 
"sporadic use" and "regular use". As it can be seen from Table 3, the majority of the companies (82.86\%) sporadically or continuously applied the hedging of transaction type exposure to currency risk and were followed by the companies that regularly or sporadically applied the hedging of translation type of currency risk (51.43\%). Only $17.14 \%$ of the respondents implemented the hedging of operating exposure to foreign exchange risk. As for changes in the application, there is an evident increasing tendency in all the types of currency risk hedging.

Both accounting data on uncollected foreign receivables and outstanding foreign liabilities, aggregate or individual by countries, operations and currencies are used in order to determine transaction exposure. For the purpose of identifying transaction exposure, accountants use multicurrency reporting forms, which include information on outstanding foreign liabilities and uncollected receivables by currency. A report on multicurrency transaction exposure contains data that do not occur in official financial reports, which can lead to positive and negative exchange rate differences, such as foreign currency forward contracts and contracted future sales and purchases. On the other hand, this report does not include items not directly associated with foreign currency transactions (e.g. cash). The following report of a multicurrency transactional exposure (Table 4) reveals the effects of changes in exchange rates on the accounting data of the Philippine branch in terms of changes in the value of the peso to the Australian dollar, the Indonesian rupee and the U.S. dollar (Choi \& Meek, 2008, 435).
Thereby, the first numerical column, containing the transaction data noted and settled in pesos, is not in the focus. It is evident that the devaluation of the Philippine currency against the Australian dollar and the U.S. dollar due to the positive net exposure in both currencies resulted in gains on a foreign currency transaction. At the same time, the devaluation of the peso relative to the Indonesian rupiah caused transaction losses owing to negative in that currency. Based on the illustrated example, which - aggregately observed - reflects the absence of transaction exposure, the importance of the currencydecomposed presentation of transaction exposure to foreign exchange risk can be argued. Despite the undeniable importance of the presentation of a multicurrency transaction exposure, the research conducted in Serbia accounted for an extremely unsatisfactory situation. In particular, $80 \%$ of the total number of the respondents negatively answered to the following question: Do you prepare a report on country- and currency-specific multi-currency transaction exposure to foreign exchange risk?

In order to hedge against transaction exposure, enterprises can use a number of operating techniques (e.g. exposure netting, payment adjustment), which is primarily used to protect the operating type of exposure to foreign currency risk. As the protection of transaction exposure to foreign exchange risk is primarily operationalized by using foreign currency financial derivatives, the key aspects of foreign currency transaction financial hedging will be presented further in the paper.

Table 3 The intensity of the application and changes in the application of certain types of currency risk hedging

\begin{tabular}{lcccccc}
\hline & \multicolumn{3}{c}{ Intensity of use } & \multicolumn{3}{c}{ Changes in the application } \\
\cline { 2 - 7 } & $\begin{array}{c}\text { No applica- } \\
\text { tion }\end{array}$ & $\begin{array}{c}\text { Sporadic } \\
\text { application }\end{array}$ & Standing & Declining & $\begin{array}{c}\text { Remain the } \\
\text { same }\end{array}$ & Growth \\
\cline { 2 - 7 } Transaction & (regular) & 6 & 23 & & 4 & 25 \\
Translation & application & 10 & 8 & 0 & 8 & 10 \\
Operating & 27 & 2 & 4 & 0 & 2 & 4 \\
\hline
\end{tabular}

Source: Author, according to the data from the Survey 
Table 4 Multiple-Currency Transaction Exposure (in \$thousand)

\begin{tabular}{lccccc}
\hline & Philippine peso & Australian dollar & $\begin{array}{c}\text { Indonesian } \\
\text { rupee }\end{array}$ & US dollar & Total \\
\cline { 2 - 6 } Exposed assets & & & & & \\
Receivables & 45.000 & 15.000 & - & 40.000 & 100.000 \\
Inventories & 90.000 & - & - & - & 90.000 \\
Future sales commitments & - & 10.000 & - & - & 10.000 \\
Total & 135.000 & 25.000 & & 40.000 & 200.000 \\
Exposed liabilities & & & & & \\
Short-term payables & 20.000 & 2.500 & 12.500 & 5.000 & 40.000 \\
Long-term debt & 50.000 & - & - & 30.000 & 80.000 \\
Future purchase commitments & - & - & 10.000 & - & 10.000 \\
Leases & - & 5.000 & - & - & 5.000 \\
Total & 70.000 & 7.500 & 22.500 & 35.000 & 135.000 \\
Net exposure & & 17.500 & $(22.500)$ & 5.000 & \\
\hline
\end{tabular}

Source: Choi \& Meek, 2008, 434

\section{THE FINANCIAL HEDGING OF TRANSACTION EXPOSURE}

Essentially, the financial hedging of foreign currency transaction (Figure 1) assumes:

- The existence of foreign exchange risk,

- The existence of the hedged item (the position effected by currency risk) and

- The use of a hedging instrument to protect against foreign exchange risk.

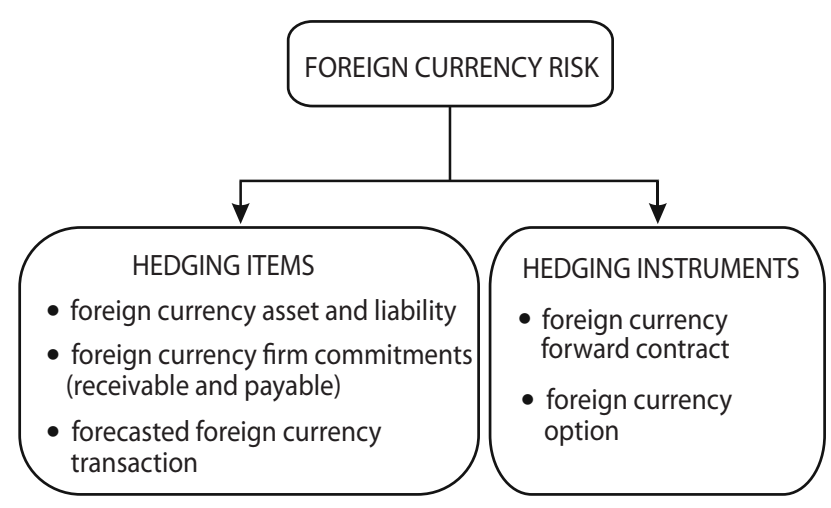

Figure 1 Currency hedging assumptions
Daily currency fluctuations and an increased integration of the world economy are the main reasons why business subjects consider foreign exchange risk as the most important type of risk. Authors F. Choi and G. Meek (Choi \& Meek, 2008, 428) use the following facts to explain the focusing of the business community on currency risk: "(1) foreign exchange risk is one of the most common forms of the risk encountered by multinational firms, (2) influential financial executives state that foreign exchange risk is one of the most difficult external risks that financial managers must cope with, and (3) risk management concepts and associated accounting treatments for foreign exchange risk parallel those for interest rate, commodity, and equity price risks." Because of the foreign exchange risk they encounter in carrying out their activities, business subjects take a number of hedging measures primarily focused on the protection of both transaction and operating exposures. Hedging is a process of protecting an entity from its exposure to risk by acquiring or creating instruments representing an offset to a certain type of risk. Accordingly, currency hedging is a connection of gains and losses on currency derivatives (hedging instruments) with losses or gains on the items that are the object of currency hedging. Companies enter into hedging arrangements in order to minimize the adverse effects of changes in 
exchange rates on cash flow and net profit. Currency hedge accounting is a specific accounting treatment which, after the establishment of hedges, enables the equalization of changes in the value of both hedging items and currency hedging instruments in the same period. The goal of currency hedge accounting is to "assure that the financial statements of entities engaged in hedging activities reflect the results of those activities" (Bierman et al, 1991, 6). Hedge accounting is also seen as a means linking the effects of the hedging components, i.e. hedged items, with hedging instruments on financial statements, thus allowing the reflection of the effectiveness of hedging relationships in financial statements. The failure of hedge accounting to show hedging activities in financial statements is metaphorically identified with a map not presenting relevant geographic features (Bierman et al, 1991, 6).

A hedged item which exposes an entity to foreign exchange risk can be a recognized asset or payable, firm commitments/unrecognized receivables or a liability and anticipated transactions expressed in foreign currencies. First of all, companies come across currency risk in selling goods on credit in the international market. In order to protect themselves against the adverse effects of changes in foreign exchange rates in collecting foreign currency receivables, companies often use currency derivatives, among which currency forwards and currency options the most predominantly used ones. The use of currency forwards will be illustrated by the example of a domestic company's import transactions. This company needs to purchase goods on credit abroad to be paid in foreign currency. Due to possible changes in the exchange rate of foreign currencies, as well as the use of payment credit conditions on the settlement of the purchase transaction, i.e. a foreign currency payable, the domestic company is said to be exposed to foreign currency risk. In order to eliminate or reduce the risk, the company can use a currency forward contract. Under this agreement, the company will receive an appropriate amount of the foreign currency on some future date at the exchange rate which the parties agreed upon today. As the result of these derivative transactions, an adverse movement in the exchange rate of the domestic and foreign currencies, which resulted in increased liabilities to the foreign supplier, is neutralized by the positive change in the currency forward contracts. While the company has made a loss on the purchase transaction, it has made a gain on the foreign exchange forward transaction. In other words, the loss on the purchase transaction is reversed by the counter derivative transaction. A currency option, giving the holder the right but not an obligation, provides a flexible hedging possibility for foreign currency trading in the future.

Companies engaged in activities denominated in foreign currencies are often included in hedging arrangements after the receipt of a non-cancellable sales order or making out of such a non-cancellable purchase order. A non-cancellable order with a specified price in a foreign currency and the date of delivery is known as a firm transaction, i.e. a firm receivable/payable in a foreign currency. Currency derivatives could be used for the hedging of firm transactions. Some companies regularly encounter foreign currency transactions that can reliably be predicted. Under such circumstances, even in the event of failure to sign a contract on future purchases, the company is exposed to currency risk. Currency derivatives can be used to protect these anticipated transactions denominated in foreign currencies.

Derivatives that companies want to use for hedge accounting must be structured for fair value hedge or the cash flow protection. For the purposes of the protection of the recognized assets and liabilities, as well as foreign currency firm transactions, the company must make a choice between these two types of determinations. On the contrary, the protection of an anticipated transaction can only be qualified as cash flow hedges. Different accounting procedures are applied for these two types of hedging. Generally speaking, while gains and losses on the fair value hedges are recognized immediately in the net profit, gains and losses on cash flow hedges are included within Other Comprehensive Income (Fraser \& Ormiston, 2013, 132).

Companies have widely and ever-increasingly been using derivatives to protect against currency risk and. The increasing tendency of using these protective creations of financial engineering in modern developed economies for the purpose of protecting against currency risk is explained by its simple application, flexibility, low transaction costs as well as a real 
opportunity to reduce or neutralize the effect of this type of risk. The increasing use of currency derivatives allows a more flexible approach in the composing of currency-sensitive assets and liabilities.

By exploring foreign exchange risk management practices in non-financial companies, a large number of authors have found a positive correlation between the level of the foreign exchange risk exposure of the company and the level of the financial derivatives use (Doupnik \& Evans, 1986; De Ceuster et al, 2000; Menon \& Viswanathan, 2005). Due to an impossibility of presenting the detailed results of the conducted original empirical research of the current state of the accounting practices of the foreign currency translation and currency hedging in the companies in the cities of Western Serbia (Dmitrović Šaponja et al, 2011), only fragmentary data relevant for testing the initial hypotheses will be displayed:

There was a statistically significant correlation between the level of the enterprise's transaction exposure to foreign exchange risk and the level of currency hedging applications.

This hypothesis is directly related to the answers to the questions as to how transaction exposure and hedging varied (moved) in the responding companies in Western Serbia in the period of 2006-2010.

To the first question of how the level of transaction exposure varied in their companies during that period, $14.29 \%$ enterprises out of the total number of the enterprises responded that the scope "fell", 5.71\% said that it "remained the same" and $80.00 \%$ of them said that it "increased".

To the second question related to the movement of the degree of the currency hedging application in their companies during the observed period, $5.71 \%$ of the companies out of the total number of the enterprises responded that the degree of the currency derivatives application "fell", 28.57\% said that it "remained unchanged", $62.86 \%$ said that it "increased", and 2.86\% of respondents provided no answer to the question.

We tested the correlation between the level of transactional exposure and the degree of the implementation of currency hedging. In order to identify the level of a quantitative congruency between the variable $X$-rated answer to the first question, and variable Y-rated answer to the second question, the simple linear correlation coefficient $R_{x y}=0,725026$ was identified.

The analysis of the statistical significance of the linear dependence and independence of variables, evaluated by $R$, was carried out by the procedure of defining and testing the null and alternative hypotheses.

The null hypothesis $\mathrm{H}_{0}: \rho=0$ means: a simple linear correlation coefficient of the population was statistically indistinguishable from zero, i.e. there is no linear correlation of the observed variables.

An alternative hypothesis $\mathrm{H}_{0}: \rho \neq 0$ means: a simple linear correlation coefficient was statistically significantly different from zero, i.e. there is a linear correlation of the observed variables.

Testing hypotheses for the samples with the number of elementary units greater than 30 was carried out by using the standardized normal distribution.

The test statistic is $z=R_{S} \sqrt{n-1}$.

The risk of error $\alpha=0,05$.

The test is a two-way test. The theoretical value $\mathrm{z}_{\alpha / 2}=1,96$.

The signing procedure is a standard procedure for the z-test.

As 35 respondents forwarded questionnaire, in this case $n=35$.

As $\mathrm{n}>30, \quad z=0,725026 \sqrt{35-1}=4,2276$.

As $|z|>z_{\alpha / 2}$ and $p<0,05$, the alternative hypothesis is accepted, which means that there is a statistically significant linear correlation between the level of transaction exposure and the degree of the implementation of currency hedging. Thus, the assertion of the initial hypotheses has been proved.

The ambitious research framework of the accounting implications of the translation and hedging of foreign currency transactions has opened a number of theoretical-methodological and application issues. 
The complexity, importance and topicality of the discussed matter implied in the introduction have been supported by highlighting the key aspects of the accounting treatment of foreign currency transactions and their hedging.

Any transaction whose terms of settlement are stated in foreign currencies could be dually observed and decomposed into two closely related parts: the monetary and the real parts. There is a widelyaccepted attitude that the translation of the transaction non-monetary part or the real assets should be based on historical exchange rates. However, when it comes to the translation of monetary assets (receivables) and liabilities, no unified attitude is adopted because of the conflict between the accrual principle and the principle of prudence.

Due to the impact of the foreign exchange rate fluctuations on foreign currency transactions, companies are faced with transaction exposure to currency risk, which upon the regulation of the transaction monetary part influences a company's flows, both cash flows and profitability flows. In particular, transaction exposure arises due to changes in the exchange rate between the time of the origin of foreign liabilities/receivables and the period of its regulation, i.e. the payment or collection, respectively. In other words, if the foreign exchange rate changes between the period of the foreign currency transaction origin and the period of its final settlement, changes in the value of corresponding foreign currency cash flows will lead to either positive or negative exchange rate differences. The importance of identifying the level of transaction exposure arises from the fact that it is an objectively conditioned exposure to foreign currency risk due to the unsettled foreign currency receivables and/or foreign currency payables that have already been established, and will be settled there has been a change in exchange rates. The justified aspiration of a company to protect itself from the effects of transaction risk is primarily operationalized by using currency derivatives, among which the most common ones are currency forwards and currency options.

The interactivity of foreign currency translation and hedging are highlighted by the theoretical consideration, and the key hypothesis has been asserted by the conducted empirical research. Besides, the empirical research has confirmed that Serbian companies are poorly acquainted not only with the accounting implications of foreign currency translation but with the possibilities of using financial derivatives for protection against currency risk, too. In this regard, companies in RS are advised to undergo staff training, i.e. to provide training to accountants and financial personnel who are not sufficiently familiar with the issues of the accounting treatment of the effects of changes in exchange rates and the use of currency derivatives. By engaging individual experts, scientific or educational institutions, they should be working on promoting the application of new theoretical and methodological knowledge in foreign currency accounting. Banks and other financial institutions in $\mathrm{RS}$ are recommended to better inform their existing and potential clients about the possibilities of the application of financial derivatives as well as to provide consulting services to companies in the practical use of currency hedging.

Apart from emphasizing the importance of the application of currency derivatives in the future, the relevant contribution of this paper is reflected in its pointing out a requirement for the implementation of the verified international achievement in the foreign currency accounting area in enterprises in RS. As an active participation in global operating, financial and investment flows assume the international convergence of the national foreign currency accounting regulations, large and small and medium enterprises in RS should, apart from offered possibilities, , consistently follow the guidelines of IAS 21.

Having in mind the effect of the Ordinance on Changes of and Amendments to the Regulation of the Chart of Accounts and Content of Accounts for Companies, Cooperatives, Legal Entities and Entrepreneurs at both the level of the treatment of foreign currency transactions and the level of currency hedging application, a future research should be focused on an analysis of the impact of the foreign currency accounting regulation on the degree of foreign currency transaction hedging. In order to exceed the main limitation of the conducted research reflected in the insufficient size of the sample, a future research should cover a great number of enterprises. It would 
be useful to explore remarks to the actual accounting regulation in the foreign currency business area, with a particular review of the non-consistent application of IAS 21.

\section{REFERENCES}

Baker, R., Lembke V., \& King, T. (2005). Advanced Financial Accounting. NY, McGraw - Hill International Edition.

Bierman, H., Johnson, T., \& Peterson, S. (1991). Hedge Accounting: An Exploratory Study of the Underlying Issues. Research Report. USA, Financial Accounting Standards Board.

Bogićević, J. (2011). Prevođenje strane valute $i$ valutni hedžing u međunarodnom računovodstou. Neobjavljena doktorska disertacija, Ekonomski fakultet u Subotici, Univerzitet u Novom Sadu.

Choi, F. (1997). International Accounting and Finance Handbook. USA, John Wiley \& Sons.

Choi, F., \& Meek, G. (2008). International Accounting. New Jersey. Pearson Education Inc.

De Ceuster, M., Durinck, E., Laveren, E., \& Lodewyckx, J. (2000). A survey into the use of derivatives by large nonfinancial firms operating in Belgium. European Financial Management, 6(3), 301-318.

Demirag, I., \& Goddard, S. (2004). Financial Management for International Business. England: McGraw-Hill International Companies.

Dhanani, A. (2003). Foreign exchange risk management: a case in the mining industry. The British Accounting Review, 35, 3563.
Dmitrović-Šaponja, Lj., Bogićević, J. i Jovetić, S. (2011). Empirijska analiza ekonomske izloženosti deviznom riziku preduzeća u Srbiji. Industrija, 39(4), 331-349.

Doupnik, T., \& Perera, H. (2007). International Accounting. Singapore: McGraw-Hill International Companies.

Fraser, L., \& Ormiston, A. (2013). Understanding Financial Statements. USA: Pearson Education Limited.

Kim, S., \& Kim, S. (2006). Global Corporate Finance. USA: Blackwell Publishing.

Madura, J., \& Fox, R. (2011). International Financial Management. China: South-Western Cengage Learning.

Menon, S., \& Viswanathan, K. G. (2005). Foreign currency risk management practices in U.S. multinationals. The Journal of International Business and Law, 4(1), 57-67.

Nobes, C., \& Parker, R. (2010). Comparative International Accounting. Harlow: Pearson Education Limited.

Pravilnik o izmenama i dopunama Pravilnika o kontnom okviru $i$ sadržini računa u Kontnom okviru za privredna društva, zadruge, druga pravna lica i preduzetnike. Službeni glasnik Republike Srbije, broj 9/2009.

Radebaugh, L., \& Gray, S. (1997). International Accounting and Multinational Enterprises. USA: John Wiley \& Sons, Inc.

Roberts, C., Weetman, P., \& Gordon, P. (2008). International Corporate Reporting. England: Prentice Hall.

Saudagaran, S. (2004). International Accounting: A User Perspective. USA: Thomson South-Western.

Shapiro, A. (2006). Multinational Financial Management. USA: John Wiley \& Sons, Inc.

Troberg, H. P. (1987). Foreign Currency Translation: A Comparative Analysis of Approaches. Advances in International Accounting, 1, 317-356.

$$
\begin{array}{r}
\text { Received on } 5^{\text {th }} \text { July 2013, } \\
\text { after revision, }
\end{array}
$$

Jasmina Bogicevic is an assistant professor at the Faculty of Economics, University of Kragujevac. She obtained her $\mathrm{PhD}$ in Economics in the field of Accounting at the Faculty of Economics in Subotica, University of Novi Sad. The key areas of her scientific interests include the specific areas of international accounting and financial accounting. 
Izvorni naučni članak

UDK: 005.334:336.764.1; 336.745; 657.631.6

doi: $10.5937 /$ ekonhor1302133B

\title{
RAČUNOVODSTVENE IMPLIKACIJE PREVOĐENJA I HEDŽINGA TRANSAKCIJA U STRANOJ VALUTI
}

\author{
Jasmina Bogićević ${ }^{*}$ \\ Ekonomski fakultet Univerziteta u Kragujevcu
}

\begin{abstract}
Usled internacionalizacije poslovanja i učestalih fluktuacija deviznih kurseva, sve više dobijaju na značaju informacije o uticaju promene kurseva razmene na finansijski i prinosni položaj kako pojedinačnih preduzeća, tako i multinacionalnih grupa. Podaci o efektima prevođenja transakcija u stranoj valuti i finansijskih izveštaja stranih filijala, izloženosti preduzeća različitim tipovima deviznog rizika i preduzetim merama valutnog hedžinga omogućavaju brojnim korisnicima računovodstvenih sadržaja sticanje bolje predstave o finansijskom i prinosnom položaju entiteta. Ključna pitanja odnose se na izbor deviznog kursa koji će se koristiti pri prevođenju računovodstvenih podataka i finansijsko-izveštajno prikazivanje efekata prevođenja. Dok se efekti prevođenja finansijskih izveštaja stranih filijala mogu prikazati u bilansu stanja i u bilansu uspeha, efekti prevođenja transakcija u stranoj valuti inkorporiraju se u bilans uspeha. U radu se razmatraju računovodstveni aspekti prevođenja transakcija u stranoj valuti, transakciona izloženost preduzeća deviznom riziku, kao i korišćenje finansijskih derivatnih instrumenata za zaštitu od deviznog rizika.
\end{abstract}

Ključne reči: transakcija u stranoj valuti, transakciona izloženost, finansijski izveštaji u stranoj valuti, valutni hedžing

JEL Classification: M41, F3

\section{UVOD}

Kompleksan delokrug međunarodnog računovodstva se najjednostavnije može sagledati na bazi njegovih deskriptivno-komparativnih i pragmatičnih domena. Dok su deskriptivno-komparativni aspekti međunarodnog računovodstva prevashodno fokusirani na istraživanje i tipologiju nacionalnih

\footnotetext{
* Korespondencija: J. Bogićević, Ekonomski fakultet Univerziteta u Kragujevcu, Đ. Pucara 3, 34000 Kragujevac, Srbija; e-mail: jasminab@kg.ac.rs
}

računovodstvenih sistema, pragmatični domeni se odnose na računovodstveni obuhvat međunarodnih transakcija i aktivnosti multinacionalnih preduzeća (MNP) (Radebaugh \& Gray, 1997, 11). Ključni pragmatični aspekti međunarodnog računovodstva odnose se na konsolidovanje, izveštavanje po segmentima, prevođenje strane valute i valutni hedžing. Značaj izučavanja ova poslednja dva interaktivna područja međunarodnog računovodstva posebno dolazi do izražaja u poslednje vreme usled ekspanzije međunarodnih poslovnih, finansijskih i 
investicionih aktivnosti, kao i izražene fleksibilnosti deviznih kurseva.

U računovodstvenom kontekstu, prevođenje strane valute (Foreign Currency Translation) predstavlja preračunavanje računovodstvenih podataka iskazanih $\mathrm{u}$ jednoj valuti $\mathrm{u}$ drugu. Neophodnost prevođenja računovodstvenih sadržaja u stranoj valuti posebno dolazi do izražaja pri evidentiranju transakcija u stranoj valuti (Foreign Currency Transactions) u poslovnim knjigama i pri pripremi finansijskih izveštaja pojedinačnog preduzeća, kao i pri konsolidovanju finansijskih izveštaja stranih filijala (Foreign Currency Financial Statements) s finansijskim izveštajima matične kompanije, pod uslovom da isti nisu iskazani u jedinstvenoj valuti (Nobes \& Parker, 2010). Usled uticaja fluktuacija deviznih kurseva na transakcije u stranoj valuti, preduzeća se suočavaju sa transakcionom izloženošću deviznom riziku (Transaction Exposure), koja se pri regulisanju monetarnog dela transakcije direktno efektuira na njihove novčane i tokove rentabiliteta. $U$ cilju zaštite od transakcione izloženosti deviznom riziku, preduzeća, uglavnom, ulaze u aranžmane finansijskog valutnog hedžinga. Ovaj tip hedžinga predstavlja povezivanje dobitaka i gubitaka na valutnim finansijskim derivatima (hedžing instrumentima) sa gubicima ili dobicima na pozicijima koje su objekat valutnog hedžinga.

Stoga će predmet istraživanja $\mathrm{u}$ radu biti usmeren na analizu interakcije prevođenja računovodstvenih sadržaja u stranoj valuti i izloženosti preduzeća različitim tipovima deviznog rizika. Konkretnije, $\mathrm{u}$ fokusu istraživanja je analiza računovodstvenih aspekata prevođenja i zaštite od valutnog rizika transakcija u stranoj valuti u uslovima fluktuacija deviznih kurseva. Polazeći od izuzetno visokog stepena dostignute ne samo de jure, već i de facto harmonizacije ovih područja međunarodnog računovodstva, kao posebno značajan aspekt istraživanja nameće se i međunarodna konvergencija računovodstvene regulative prevođenja strane valute i njene reperkusije na privredu Republike Srbije (RS).

Imajući u vidu prethodno definisan i obrazložen predmet istraživanja, osnovni cilj rada je da se, na bazi razmatranja konceptualnih pitanja prevođenja transakcija i transakcione izloženosti deviznom riziku, ukaže na njihovu interakciju sa valutnim hedžingom, kao $\mathrm{i}$ da se te kauzalne relacije interpretiraju $\mathrm{u}$ računovodstvenom kontekstu. Značajni ciljevi istraživanja ogledaju se i u sagledavanju efekata prevođenja transakcija $u$ stranoj valuti i valutnog hedžinga na finansijski i prinosni položaj preduzeća, kao i u analizi postojećih praksi računovodstvenog tretmana efekata promena deviznih kurseva $\mathrm{u}$ reprezentativnim preduzećima u RS.

Shodno izloženom predmetu i postavljenim ciljevima istraživanja, u radu će biti testirana sledeća hipoteza: postoji statistički značajna međuzavisnost između nivoa transakcione izloženosti preduzeća deviznom riziku i stepena primene valutnog hedžinga.

Nakon definisanja problema, predmeta, ciljeva istraživanja i postavljanja istraživačke hipoteze, usledilo je detaljno upoznavanje sa literaturom iz oblasti računovodstva strane valute (Foreign Currency Accounting). Razumevanje tih kompleksnih teorijskometodoloških aspekata omogućilo je upoznavanje sa slučajevima iz prakse stranih pojedinačnih i multinacionalnih preduzeća, kao i njihovo poređenje sa praksom domaćih entiteta. Anketnim istraživanjem reprezentativnih preduzeća u RS, koja se suočavaju s transakcijama u stranoj valuti i valutnim hedžingom, došlo se do relevantnih empirijskih saznanja o ključnim problemima prevođenja računovodstvenih sadržaja u stranoj valuti i mogućnostima primene inostranih dostignuća za njihovo rešavanje. U procesu istraživanja korišćen je širok spektar metodskih postupaka i tehnika koje omogućavaju verifikaciju postavljene hipoteze. Najzad, najvažniji rezultati teorijskoempirijskog istraživanja računovodstvenih implikacija prevođenja strane valute i valutnog hedžinga biće razumevanje interaktivnosti ovih područja, afirmacija međunarodne konvergencije regulative računovodstva strane valute, kao i analitička interpretacija efekata primene raznih metoda prevođenja transakcija u stranoj valuti na finansijski i prinosni položaj preduzeća.

Korespondentno opredeljenom predmetu, ciljevima i polaznoj hipotezi, u radu će, nakon razmatranja računovodstvenih aspekata prevođenja strane valute, biti izložen računovodstveni tretman transakcija $u$ stranoj valuti. Zatim će biti razmatrana transakciona 
izloženost preduzeća deviznom riziku. Poslednji deo rada biće posvećen finansijskom hedžingu transakcija $\mathrm{u}$ stranoj valuti. Pri tome, umesto inicijalnog, integrativnog pregleda prethodnih istraživanja, biće zastupljen sekvencijalni pregled literature u svakom segmentu rada.

\section{RAČUNOVODSTVENI ASPEKTI PREVOĐENJA STRANE VALUTE}

U ekonomskoj literaturi se ističe specifično značenje sintagme prevođenje strane valute (Foreign Currency Translation). U računovodstvenom kontekstu prevođenje strane valute predstavlja proces izražavanja finansijskih podataka iskazanih $\mathrm{u}$ jednoj valuti $\mathrm{u}$ drugu primenom odgovarajućih kurseva razmene. Pri tome, $\mathrm{u}$ procesu promene monetarnog izraza iznosa iskazanih u stranoj valuti na domaći valutni ekvivalent mogu se koristiti istorijski, tekući ili prosečni kursevi.

Dok konverzija implicira realnu, fizičku zamenu jedne valute za drugu, računovođe koriste prevođenje strane valute s ciljem da se zadovolji uslov valutne homogenosti finansijskih podataka. Kako su računovođe engleskog govornog područja ovaj termin preuzele od lingvista, izvan računovodstvenih krugova često dolazi do pogrešne interpretacije i upotrebe termina prevođenje (Nobes \& Parker, 2010, 412).

Generalno, razloge za prevođenje finansijskih podataka iskazanih $\mathrm{u}$ stranoj valuti treba posmatrati $\mathrm{u}$ kontekstu ekspanzije međunarodnih poslovnih, finansijskih i investicionih aktivnosti, povećanja broja multinacionalnih grupa, frekventnih fluktuacija deviznih kurseva i rastućeg značaja finansijskoizveštajne transparentnosti efekata intervalutarnih kolebanja na finansijski i rentabilitetni položaj preduzeća. Adekvatno prevedeni finansijski podaci ne samo da eliminišu asimetričnost informacija između domaćih i inostranih korisnika računovodstvenih sadržaja, već predstavljaju i conditio sine qua non konsolidovanja finansijskih izveštaja međunarodnih grupa i izveštavanja po segmentima. Neophodnost prevođenja računovodstvenih podataka javlja se $u$ brojnim situacijama kako na nivou pojedinačnih preduzeća, tako i na nivou međunarodnih grupa. Problem prevođenja transakcija u stranoj valuti javlja se pri evidentiranju istih u poslovnim knjigama i pri pripremanju finansijskih izveštaja individualnog preduzeća. Značaj prevođenja, kao procesa preformulisanja informacionih sadržaja finansijskih izveštaja iskazanih $u$ jednoj valuti $u$ drugu, posebno dolazi do izražaja kada MNP pripremaju konsolidovane finansijske izveštaaje. Postoje i drugi razlozi koji uslovljavaju potrebu za prevođenjem strane valute, među kojima se posebno ističu: izveštavanje o rezultatima nezavisnih aktivnosti u inostranstvu, izveštavanje o aktivnostima međunarodnih filijala $\mathrm{i}$ podružnica, kao i njihovih menadžera.

Iako je, na prvi pogled, problematika prevođenja strane valute izgubila na značaju u zemljama Evro zone $z b o g$ demonetizacije nacionalnih valuta većine članica Evropske unije, sa sigurnošću se može i dalje potkrepiti nesporan značaj ovog računovodstvenog područja sledećim argumentima:

- zemlje članice Evropske unije, pored intragrupacijskih ekonomskih komunikacija koje se odvijaju u jedinstvenoj valuti, i dalje obavljaju poslovne, finansijske i investicione aktivnosti izvan Evro zone;

- pošto neke zemalje (na primer, Velika Britanija, Danska i zemlje koje su nedavno stekle status članica Evropske unije) nisu izvršile demonetizaciju nacionalnih valuta $\mathrm{u}$ evro, $\mathrm{i}$ dalje je prisutna valutna heterogenost na području Evropske unije; čak i intragrupacijski ekonomski odnosi između svih zemalja članica ne obavljaju se na jedinstvenoj valutnoj osnovi; drugim rečima, Uniju karakteriše multivalutno okruženje.

Ilustrativno obrazloženje nespornog značaja prevođenja strane valute veoma jasno otkriva opšteprihvaćena konstatacija F. Choi-a, koja glasi: "Izabrane metode za prevođenje strane valute predstavljaju srž fundamentalnih koncepata koji čine osnovu sadašnjeg finansijskog izveštavanja" (Choi, 1997, 13.2). Vodeći autori u oblasti međunarodnog računovodstva ističu da prevođenja strane valute i korespondentan valutni hedžing predstavljaju najkompleksnije i najkontroverznije aspekte međunarodnog finansijskog izveštavanja. Brojne studije, posvećene istraživanju 
relativnog značaja specifičnih problema iz oblasti međunarodnog računovodstva, već duže vreme ističu njihov primat. S tim u vezi, H. P. Troberg $(1987,318)$ navodi i numeričku argumentaciju ove konstatacije, ističući da su "vodeći eksperti u oblasti međunarodnog računovdstva konstatovali da se na listi od deset fundamentalnih problema (od ukupno razmatranih osamdeset osam) pet odnosi na prevođenje strane valute." I T. Doupnik i H. Perera (2007, VI) navode rezultate dva različita pregleda stavova poslovnih izvršilaca koji smatraju da se najvažnije teme koje treba razmatrati na kursevima međunarodnog računovodstva odnose na računovodstvo strane valute (Foreign Currency Accounting).

U releavantnoj literaturi dominira shvatanje da prevođenje strane valute predstavlja problem upravo zbog učestalih fluktuacija deviznih kurseva koje povećavaju broj korišćenih kurseva razmene u procesu prevođenja. Argumentovanost ove konstatacije metaforički potvrđuju F. Choi i G. Meek $(2008,204)$ ističući "da su devizni kursevi relativno stabilni, prevođenje strane valute ne bi bilo teže od pretvaranja inča i stopa u njihove metrične ekvivalente."

Nepostojanje fiksnih deviznih kurseva postavlja pred računovođe dva pitanja:

- koji devizni kurs (istorijski ili tekući) koristiti za prevođenje sredstava i obaveza iskazanih u stranoj valuti,

- kako računovodstveno tretirati dobitke ili gubitke koji nastaju usled promene deviznih kurseva?

Kako primenjeni devizni kurs određuje vrednost sredstava i obaveza preduzeća, a efektuira se i pri obračunavanju rezultata, prvom pitanju treba posvetiti maksimalnu pažnju. Drugi problem se odnosi na prezentiranje, tj. na deskriptivno opredeljenje i finansijsko-izveštajno pozicioniranje efekata prevođenja, ili kako ih Flower (prema: Nobes \& Parker, 2010, 415) kvalifikuje kao translacione razlike (Translation Differences). Bilansna dispozicija ovih translacionih razlika utiče na mnoge značajne finansijske indikatore, kao što su neto dobitak, ukupna sredstva, sopstveni kapital, racio zaduženosti, prinos na sopstveni kapital i dr.
Računovodstveni aspekti prevođenja strane valute podrazumevaju obradu sledećih ključnih pitanja, i to:

- prevođenja transakcija u stranoj valuti (Foreign Currency Transaction Translation), i

- prevođenja finansijskih izveštaja u stranoj valuti (Foreign Currency Financial Statements Translation).

Iako metodološki kompleksna, pitanja koja se odnose na tretman transakcija $u$ stranoj valuti i njihovog valutnog hedžinga uglavnom se $u$ relevantnoj računovodstvenoj literaturi uniformno interpretiraju. Međutim, $u$ vezi sa prevođenjem finansijskih izveštaja stranih filijala iskazanih u stranoj valuti javljaju se brojne kontroverze, koje najvećim delom proizlaze iz različitog tumačenja sledećih konceptualnih pitanja:

- izbora deviznih kurseva za pretvaranje iznosa iskazanih u jednoj valuti u drugu, $i$

- finansijsko-izveštajnog pozicioniranja efekata prevođenja.

$\mathrm{U}$ zavisnosti od primenjenih deviznih kurseva $\mathrm{u}$ postupku prevođenja finansijskih izveštaja stranih filijala na jedinstven valutni ekvivalent, izdiferencirale su se brojne metode, i to metoda tekućeg kursa, tekuće/ netekuća metoda, monetarna/nemonetarna metoda i temporalna metoda. Korišćenje različitih metoda prevođenja finansijskih izveštaja ima za posledicu širok opseg translacionih rezultata, različite iznose neto imovine, kao i različitu translacionu izloženost valutnom riziku.

Zbog tematske opredeljenosti ovog rada dominantan značaj u daljim razmatranjima imaće računovodstvene implikacije prevođenja transakcija $u$ stranoj valuti i konsekutivna transakciona izloženost deviznom riziku. U cilju integralnog sagledavanja relevantnih računovodstvenih implikacija efekata promena deviznih kurseva na transakcije u stranoj valuti razmotriće se i ključni aspekti hedžinga transakcione izloženosti. Fokusiranost na transakcionu izloženost ne znači da prisustvo ostalih tipova deviznog rizika treba marginalizovati. Jednostavno, minucioznije bavljenje njima prevazilazi okvire ovog rada. 


\section{RAČUNOVODSTVENI TRETMAN TRANSAKCIJA U STRANOJ VALUTI}

Računovođe se suočavaju sa problemom prevođenja transakcija $\mathrm{u}$ stranoj valuti $\mathrm{u}$ kontekstu njihovog evidentiranja $u$ poslovnim knjigama, kao i pri pripremanju seta finansijskih izveštaja na nivou individualnih preduzeća. Reč je, u stvari, o onim transakcijama koje podrazumevaju izvršenje, tj. naplatu potraživanja ili isplatu obaveza u stranoj valuti. Pri tome, neophodno je praviti striktnu razliku između transakcija u stranoj valuti, s jedne strane, i spoljnotrgovinskih, tj. uvozno-izvoznih transakcija, s druge strane. Naime, u bilo kojoj međunarodnoj transakciji samo jedan akter se suočava s problemom računovodstvenog tretmana istih u stranoj valuti, zato što se plaćanje uobičajeno specificira $u$ jednoj valuti. Shodno tome, samo ona strana koja reguliše obavezu ili potraživanje $\mathrm{u}$ bilo kojoj drugoj valuti osim njene nacionalne suočava se s transakcijama u stranoj valuti. Pored kupoprodajnih aktivnosti, transakcije u stranoj valuti uglavnom obuhvataju plasiranje sopstvenih ili pozajmljivanje tuđih sredstava, kao i naplatu i isplatu dividendi (Roberts et al, 2008, 181). R. Baker i ostali $(2005,544)$ na sličan način specificiraju transakcije u stranoj valuti:

- "izvozno-izvozne transakcije ukoliko se cene, odnosno, uslovi plaćanja navode u stranoj valuti;

- davanje i korišćenje pozajmica (kreditni aranžmani) u stranoj valuti;

- kupovina ili prodaja valutnih terminskih ugovora;

- kupovina ili prodaja strane valute."

Računovođe su zauzele jedinstven stav da inicijalno knjigovodstveno evidentiranje transakcije $u$ stranoj valuti treba bazirati na efektivnom kursu na dan transakcije. Zbog mogućnosti korišćenja kreditnih uslova u periodu fluktuacije deviznih kurseva bilo koji nerealizovan deo transakcije (neizmirenu obavezu i/ ili nenaplaćeno potraživanje $u$ stranoj valuti), treba prilagoditi na dan međubilansa. Međutim, ako se iznos pri izvršenju transakcije razlikuje $u$ odnosu na prethodno evidentiran, računovođe se suočavaju s problemom tretmana utvrđene razlike, odnosno, dobitaka i gubitaka na transakciji u stranoj valuti. $\mathrm{S}$ tim $\mathrm{u}$ vezi, izdiferencirala su se dva gledišta, i to: perspektiva jedne transakcije i perspektiva dve transakcije (Choi \& Meek 2008, 209).

Prema prvom shvatanju, i realni i monetarni deo transakcije u stranoj valuti tretiraju se kao delovi jedinstvenog poslovnog događaja. Naime, isplata obaveze ili naplata potraživanja $u$ stranoj valuti smatraju se neophodnim i nerazdvojnim delom transakcije nabavke ili prodaje, respektivno. Prema perspektivi jedne transakcije, efekti promene deviznih kurseva pri prodaji robe na kredit inokupcu knjigovodstveno se obuhvataju na kontima Ino-potraživanja i Prihodi od prodaje. Kako se konta uspeha zatvaraju na kraju perioda, negativni efekti promene kurseva razmene na početku perioda bi se obuhvatili na kontu Neraspodeljena dobit. Stoga se ovoj perspektivi može uputiti primedba da se, korigovanjem Prihoda od prodaje, odnosno Neraspodeljene dobiti za efekte promena deviznih kurseva, u uslovima korišćenja kreditnih uslova plaćanja, maskiraju kursne razlike.

Prema drugom shvatanju, transakcije u stranoj valuti se dekomponuju na realni i monetarni segment i zasebno se tretiraju kupovina ili prodaja robe, s jedne strane, i regulisanje obaveze ili potraživanja, s druge strane. Drugim rečima, ova perspektiva tretira izvoz i korespondentnu naplatu kao dve posebne transakcije. Pošto uprava donosi dve odluke o realizaciji proizvoda na ino-tržištu, kao i o ponudi kreditnih uslova plaćanja ino-kupcu, posebno se iskazuju efekti obe ove odluke u bilansu uspeha. Razlika između iznosa inicijalno zabeleženog na dan transakcije i iznosa po kom se vrši konačno regulisanje iste, tretira se kao dobitak ili gubitak od transakcije u stranoj valuti, odnosno, transakcioni dobitak ili gubitak (Transaction Gain / Transaction Loss). Drugim rečima, prema ovom shvatanju, ne vrši se korigovanje inicijalno evidentiranog Prihoda od prodaje, već se efekti promene deviznih kurseva na potraživanja $u$ stranoj valuti iskazuju preko Pozitivnih ili Negativnih kursnih razlika.

Poređenjem ovih perspektiva možemo zaključiti da se obe na isti način efektuiraju na uspeh preduzeća. Razlika se svodi na to da perspektiva jedne transakcije menja iznos poslovnih prihoda, a efekti transparentnije 
perspektive dve transakcije se obuhvataju preko finansijskih rashoda ili prihoda.

Pri razmatranju efekata fluktuacija deviznih kurseva $\mathrm{u}$ kontekstu računovodstvenog obuhvata transakcija u stranoj valuti, neophodno je osvrnuti se i na problem nepostojanja jedinstvene, standardne metode za prevođenje monetarnog dela transakcija u stranoj valuti. S tim u vezi, računovođe su zauzele stav da prevođenje realnog dela transakcije $u$ stranoj valuti treba zasnivati na istorijskim, tj. transakcionim kursevima. Nasuprot tome, za prevođenje monetarne aktive (potraživanja) i obaveza iskazanih $\mathrm{u}$ ino-valuti Flower (prema: Nobes \& Parker, 2010, 417) navodi tri modaliteta prevođenja :

“(1) prema istorijskom kursu (historical rate); po ovoj metodi iznosi onih pozicija iskazanih u nacionalnoj valuti ostaju nepromenjeni i ne iskazuju se dobici ili gubici od prevođenja (translation gains/losses);

(2) prema tekućem kursu (closing rate); prevođenje po kursu na dan bilansa rezultira u tekućoj vrednosti ovih pozicija u nacionalnoj valuti, tj. u novčanom ekvivalentu do koga bi se došlo konverzijom monetarne aktive $\mathrm{u}$ nacionalnu valutu (mutatis mutandis obaveze); ukoliko se tekući kurs razlikuje $\mathrm{u}$ odnosu na istorijski, javljaju se translatorne razlike, koje se generalno uključuju u bilans uspaha kao dobici ili gubici od prevođenja;

(3) po nižem (višem) istorijskom ili tekućem kursu za sredstva (obaveze); u uslovima primene ove metode, sredstva se iskazuje po nižoj, a obaveze po višoj alternativnoj vrednosti; tekući kurs se jedino koristi ukoliko rezultira u gubitku od prevođenja, koji se iskazuje u bilansu uspeha."

Kako prva metoda može dovesti do precenjivanja monetarne aktive i potcenjivanja obaveza $\mathrm{u}$ odnosu na njihove tekuće vrednosti, može se konstatovati da je u direktnoj suprotnosti sa principom opreznosti. Stoga se s pravom dovodi u pitanje argumentovanost $i$ validnost ovakvog pristupa. Za razliku od ove metode, $\mathrm{u}$ računovodstvenoj literaturi nailazimo na dobro fundirane argumente, koji apostrofiraju primenu drugog i trećeg pristupa.
Druga metoda se bazira na principu uzročnosti, po kojem efekte prevođenja monetarnog dela transakcija u stranoj valuti (transakcione dobitke i gubitke) treba dodeliti onom obračunskom periodu u kom je došlo do promene deviznog kursa, a ne u periodu naplate ili isplate gotovine i njenih ekvivalenata.

I regulatorne vlasti u SAD i Velikoj Britaniji i ostalim zemljama sa anglosaksonskim stilom računovodstva zastupaju stav o obračunskom alociranju dobitaka ili gubitaka od prevođenja transakcija u stranoj valuti, budući da su ove translacione razlike prouzrokovane promenom deviznog kursa do koje je došlo upravo tokom odnosnog obračunskog intervala. Dakle, i američki Iskaz 52, Prevođenje strane valute (objavljen 1981. godine), koji je Odlukom Odbora za standarde finansijskog računovodstva (Financial Accounting Standard Board - FASB) od 15. septembra 2009. godine, pod oznakom ASS 830 zvanično postao deo Accounting Standards Sodification, i britanski istoimeni Iskaz 20 uglavnom slede metodu u čijoj je osnovi princip uzročnosti. Sličan pristup zastupljen je i u Međunarodnom računovodstvenom standardu 21 (MRS 21), Efekti promene kurseva razmene.

Treća metoda se bazira na principu opreznosti. U kontekstu transakcija u stranoj valuti, ovaj princip se operacionalizuje tako što se za preračunavanje monetarne aktive i obaveza, pri izboru između istorijskog ili tekućeg kursa, koristi devizni kurs koji reperkutuje nižu vrednost sredstava, odnosno, višu vrednost obaveza. Zbog mogućnost kretanja deviznih kurseva u suprotnom smeru u budućnosti, koji mogu neutralisati pozitivne efekte $\mathrm{u}$ tekućem periodu, "oprezne" računovođe nisu spremne da iskažu dobitke od prevođenja monetarnog dela transakcije $\mathrm{u}$ tekućem periodu, već ih odlažu za period u kom će se definitivno regulisati potraživanja ili obaveze u starnoj valuti.

Za razliku od većine zemalja EU, čija nacionalna pravila zagovaraju primenu tekućeg kursa pri prevođenju monetarnih sredstava, u Nemačkoj i Francuskoj se favorizuje konzervativniji pristup po kojem se monetarna sredstva prevode po nižem istorijskom ili tekućem kursu, a za prevođenje obaveza u stranoj valuti koristi se viši istorijski ili tekući kurs. Evidentno je, dakle, da ova metoda nalazi primenu u 
onim zemljama koje daju prioritet principu opreznosti (Nemačka i Francuska).

Rezimirajući razmatranja pragmatične vrednosti ovih metoda, Flower (prema: Nobes \& Parker, 2010, 419) konstatuje da je najbolje rešenje ono koje se zasniva na kompromisnom tretmanu obe metode i navodi da je "uobičajeno da se monetarna aktiva i obaveze vrednuju na bazi tekućeg kursa, a da se transfer pozitivnih efekata u bilans uspeha odloži za onaj period u kojem će se izvršiti potraživanje/obaveza u stranoj valuti."

U osnovi originalnog empirijskog istraživanja autora sprovedenog 2010. godine, tokom izrade doktorske disertacije (Bogićević, 2011), jeste sagledavanje računovodstvenih implikacija prevođenja transakcija u stranoj valuti, kao i analiza primenjenih, postojećih praksi upravljanja valutnim rizikom u reprezentativnim preduzećima u RS.

Pored problema računovodstvenog obuhvata transakcija u stranoj valuti, istraživane su i primedbe na aktuelnu računovodstvenu regulativu $\mathrm{u}$ oblasti deviznog poslovanja sa posebnim osvrtom na konzistentnost primene MRS 21.

$\mathrm{U}$ pogledu računovodstvenog tretmana transakcija $\mathrm{u}$ stranoj valuti u preduzećima u RS, najveći broj anketiranih ispitanika ukazao je na problem njihovog nekonzistentnog finansijsko-izveštajnog prikazivanja nakon objavljivanja Pravilnik o izmenama $i$ dopunama Pravilnika o Kontnom okviru i sadržini računa u Kontnom okviru za privredna društva, zadruge, druga pravna lica $i$ preduzetnike (Službeni glasnik RS, broj 9/2009). Naime, usled iskazanih velikih negativnih kursnih razlika koje bi se iskazale kao rashodi u bilansu uspeha preduzeća u Srbiji, Pravilnik je, dozvoljavajući njihov transfer na vremenska razgraničenja, repozicionirao efekte promene deviznih kurseva iz bilansa uspeha $\mathrm{u}$ bilans stanja. Time ne samo da je dovedena u pitanje interperiodična uporedivost finansijskog i prinosnog položaja preduzeća, već i primena dela MRS 21 koji se odnosi na transakcije u stranoj valuti.

Vremensko razgraničenje efekata kursnih razlika utiče već duži niz godina na finansijski i prinosni položaj velikog broja preduzeća u RS. Treba imati u vidu i činjenicu da će prenos razgraničenih efekata kursnih razlika na prihode i rashode odgovarajućeg obračunskog perioda uticati i na finansijske izveštaje narednih godina.

\section{TRANSAKCIONA IZLOŽENOST PREDUZEĆA DEVIZNOM RIZIKU}

Internacionalizacija ekonomskih aktivnosti praćena porastom međuvalutne nestabilnosti usmerava globalno orijentisano preduzeće na veću percepciju izloženosti deviznom riziku i valutni hedžing. Kako ističe S. Saudagaran $(2004,59)$, izloženost deviznom riziku predstavlja "meru potencijalne promene profitabilnosti, tokova gotovine i tržišne vrednosti preduzeća usled promene deviznih kurseva." Pri tome, opšti koncept izloženosti deviznom riziku se $\mathrm{u}$ literaturi ne posmatra monolitno, već se dekomponuje na transakcioni, translacioni i ekonomski segment (Demirag \& Goddard, 1994; Dhanani, 2003; Menon \& Viswanathan, 2005; Kim \& Kim, 2006; Madura \& Fox, 2011). A. Shapiro (2006) klasifikuje izloženost deviznom riziku na transakcionu, translacionu i operativnu komponentu. U tom slučaju, radi se o ekonomskoj izloženosti u širem smislu, koja obuhvata transakcionu i operativnu komponentu. Iako ovi alternativni tipovi izloženosti odražavaju devizni rizik iz različitih perspektiva i između njih postoji znatan stepen podudarnosti, neophodno ih je posebno identifikovati. Navedene vrste izloženosti deviznom riziku ne samo da na različit način utiču na postojeći i potencijalni finansijski i prinosni položaj entiteta, već impliciraju i primenu različitih hedžing strategija.

U Tabeli 1 ilustrovano je suštinsko određenje transakcione, translacione i operativne izloženosti. $\mathrm{Na}$ bazi toga možemo konstatovati da se, usled preplitanja između navedenih tipova izloženosti deviznom riziku, ne može povući jasna demarkaciona linija između njih.

Usled uticaja fluktuacija deviznih kurseva na transakcije u stranoj valuti, preduzeća se suočavaju sa transakcionom izloženošću deviznom riziku, koja se pri regulisanju monetarnog dela ovih transakcija direktno efektuira na novčane i tokove rentabiliteta. Pošto ove transakcije rezultiraju u budućim prilivima i odlivima novca u stranoj valuti, promena deviznog kursa $\mathrm{u}$ periodu od njihovog knjigovodstvenog 
Tabela 1 Poređenje translacione, transakcione i operativne izloženosti

\section{Translaciona izloženost}

Promene pozicija bilansa uspeha i pozicija bilansa stanja (aktive i obaveza) prouzrokovane promenom deviznog kursa. Proizlazeće pozitivne i negativne kursne razlike određene su računovodstvenim pravilima i predstavljaju samo kategorije "na papiru". Merenje translacione izloženosti je retrospektivno prema karakteru i zasniva se na aktivnostima koje su se već odigrale.

Utiče na: postojeće pozicije bilansa stanja i bilansa uspeha.

\begin{abstract}
Operativna izloženost
Promene iznosa budućih tokova gotovine iz poslovanja prouzrokovane promenom deviznog kursa. Proizlazeće pozitivne ili negativne kursne razlike određene su promenama buduće konkurentske pozicije preduzeća i realne su. Merenje operativne izloženosti je prospektivno po karakteru i bazira se na budućim aktivnostima.
\end{abstract}

Utiče na: prihode i rashode u vezi sa budućim prodajama.

PROMENA DEVIZNOG KURSA

Utiče na: već sklopljene ugovore koji će se izvršiti kasnije

\section{Transakciona izloženost}

Promene u vrednosti neizmirenih ugovora izraženih u stranoj valuti (na primer, ugovori iz kojih proizlaze tokovi gotovine) do kojih dolazi zbog promene deviznog kursa. Rezultirajuća pozitivna ili negativna kursna razlika određena je tipom već sklopljenog ugovora i realna je. Kako se zasniva na odigranim aktivnostima u prošlosti koje će se regulisati u budućnosti, merenje transakcione izloženosti kombinuje retrospektivnu i progresivnu dimenziju. Već bilansirani ugovori su delovi translacione, a oni koji nisu iskazani u bilansu stanja predstavljaju segmente operativne izloženosti.

Izvor: Shapiro, 2006, 328

obuhvatanja do njihovog izmirenja usloviće promenu iznosa priliva ili odliva novca u domaćoj valuti. Transakciona izloženost se odnosi na potencijalne promene vrednosti neizvršenih potraživanja i obaveza koje se iskazuju u stranoj valuti zbog mogućnosti promene deviznog kursa $\mathrm{u}$ periodu od sklapanja ugovora do njegovog izvršenja. Kao kratkoročna komponenta ekonomske izloženosti posmatrane $\mathrm{u}$ širem smislu, transakciona izloženost proizlazi iz širokog spektra transakcija koje se regulišu isključivo u stranoj valuti. Ovaj tip izloženosti deviznom riziku je prisutan kada su novčani tokovi određene transakcije $\mathrm{u}$ stranoj valuti pod uticajem promena deviznih kurseva i "proizlazi iz neobezbeđenih novčanih tokova" (Nobes \& Parker, 2010, 571).

Mada je istaknuto da transakciona izloženost predstavlja deo ekonomske izloženosti u širem smislu, ona se uglavnom "stavlja $\mathrm{u}$ isti koš" sa translacionom izloženošću. "U stvarnosti, prepliće se i sa translacionom i sa operativnom izloženošću deviznom riziku" (Shapiro, 2006, 338). Naime, pojedine komponente transakcione izloženosti (potraživanja i obaveze u stranoj valuti) zbog njihovog inkorporiranja $\mathrm{u}$ bilans stanja predstavljaju, istovremeno, i segment translacione izloženosti deviznom riziku. S druge strane, pojedini elementi transakcione izloženosti, kao što su, na primer, ugovori o anticipiranoj kupoprodajnoj transakciji u stranoj valuti ne predstavljaju bilansne pozicije. Shodno tome, oni nisu deo translacione, već operativne izloženosti.

U slučaju devalvacije strane valute pri naplati potraživanja smanjio bi se primljeni iznos konvertovan u domaću valutu. Naime, ako bi primanja izložena deviznom riziku prevazišla izložena plaćanja, depresijacija stane valute bi dovela do negativnih, a apresijacija do pozitivnih kursnih razlika. $S$ druge strane, ako bi iznos izloženih obaveza u stranoj valuti prevazišao iznos potraživanja, depresijacija strane valute bi dovela do pozitivnih kursnih razlika. Nasuprot tome, apresijacija bi produkovala negativne kursne razlike. I. Demirage i S. Goddard $(1994,95)$ dekomponuju transakcionu izloženost na zatvorenu i otvorenu. Dok se zatvorena transakciona izloženost dovodi $u$ vezu sa već izvršenim transakcijama $u$ stranoj valuti po kursu koji se razlikuje od kursa koji je korišćen pri početnom vrednovanju ino-potraživanja ili ino-obaveze, otvorena izloženost se odnosi na još neizvršene transakcije u stranoj valuti. 
Dinamički posmatrano, transakciona izloženost se može podeliti na (Saudagaran, 2004, 60):

- "izloženost cene (quotation exposure), koja obuhvata period od momenta određivanja cene od strane prodavca do momenta prijema porudžbine kupca;

- izloženost zaliha (backlog exposure), koja obuhvata period od prijema porudžbine do isporuke robe i njenog fakturisanja;

- izloženost naplate (billing exposure), koja se odnosi na period od momenta isporuke do naplate fakture."

Iako se sve navedene komponente transakcione izloženosti mogu kvantifikovati, za finansijsko izveštavanje relevantna je samo poslednja navedena mera, tj. stepen izloženosti naplate deviznom riziku.

Značaj identifikovanja stepena transakcione izloženosti proizlazi iz činjenice da se radi o objektivno uslovljenoj izloženosti deviznom riziku usled neregulisanih ino-potraživanja i/ili ino-obaveza koji su formirani pre, a izvršiće se nakon promena deviznih kurseva. Brojna empirijska istraživanja potvrđuju najveći relativni značaj transakcione izloženosti deviznom riziku kako u pogledu pažnje koja se posvećuje ovom tipu izloženosti u praksi, tako i u pogledu hedžing preferencija finansijskih menadžera. Pregledom 125 američkih multinacionalnih preduzeća Malindretos i Tsanacas (Kim \& Kim, 2006, 236) su utvrdili da skoro $2 / 3$ ispitanih finansijskih menadžera najveći značaj pridaju transakcionoj izloženosti. Najveći značaj ekonomskoj izloženosti dalo je $26 \%$ ispitanih finansijskih menadžera, a samo $13 \%$ ispitanika najveći značaj pridaju translacionoj izloženosti. Pregledom je, takođe, konstatovano da se $65 \%$ kompanija štiti od transakcione izloženosti deviznom riziku, a samo $26 \%$ finansijskih menadžera iz posmatranog uzorka sprovode mere hedžinga translacione izloženosti valutnom riziku. Ispitani menadžeri poklanjaju neznatnu pažnju translacionoj i operativnoj izloženosti deviznom riziku, zato što smatraju da ova dva tipa nemaju značaj koji pripada transakcionom tipu izloženosti. Relativni značaj različitih vrsta izloženosti deviznom riziku prikazan je u Tabeli 2.
Tabela 2 Relativni značaj različitih tipova izloženosti deviznom riziku

\begin{tabular}{lcc}
\hline Tip izloženosti & $\begin{array}{c}\text { Najvažniji tip } \\
\text { izloženosti }\end{array}$ & $\begin{array}{c}\text { Hedžing } \\
\text { preferencije }\end{array}$ \\
\hline Translaciona izloženost & $13 \%$ & $26 \%$ \\
Transakciona izloženost & $64 \%$ & $65 \%$ \\
Operativna izloženost & $26 \%$ & $39 \%$ \\
\hline
\end{tabular}

Izvor: Kim \& Kim, 2006, 236

Za potrebe istraživanja intenziteta primene i promena $\mathrm{u}$ primeni pojedinih tipova zaštite od izloženosti valutnom riziku u RS autor je prosledio Anketni upitnik na preko 60 adresa. Na upitnik je odgovorilo 35 preduzeća, a preko 15 preduzeća se izvinilo da, zbog nepoznavanja problematike, nije $u$ mogućnosti da odgovori na postavljena pitanja. Sa aspekta delatnosti, 19 anketiranih jedinica, ili 54,29\%, je proizvodnih, a 16 ili 45,71\% pripada kategoriji trgovinskih preduzeća. Pri tome, 25 anketiranih entiteta predstavljaju deo grupe za koju se sastavljaju konsolidovani finansijski izveštaji. Istraživanjem nisu obuhvaćene finansijske institucije, već isključivo privredna društva. Ispitanici su zamoljeni da navedu intenzitet primene pojedinih tipova zaštite od valutnog rizika, pri čemu su im bili navedeni odgovori: "nema primenu", "sporadična primena" i "stalna primena". Kao što se može videti iz Tabele 3, najveći broj preduzeća $(82,86 \%)$ sporadično ili stalno primenjuje transakcioni tip zaštite od valutnog rizika, nakon čega slede preduzeća koja stalno ili sporadično primenjuju translacioni tip zaštite od valutnog rizika (51,43\%). Samo $17,14 \%$ respondenata primenjuje operativni tip zaštite od deviznog rizika. U pogledu promena u primeni, evidentna je tendencija porasta kod svih tipova zaštite od valutnog rizika.

U cilju utvrđivanja transakcione izloženosti koriste se računovodstveni podaci o nenaplaćenim inopotraživanjima i neizmirenim ino-obavezama kako agregatno, tako i po pojedinim zemljama, operacijama i valutama. Za potrebe identifikovanja transakcione izloženosti, računovođe koriste multivalutne izveštajne forme, koje sadrže podatke o neizmirenim ino-obavezama i nenaplaćenim potraživanjima po valutama. Izveštaj o multivalutnoj transakcionoj 
Tabela 3 Intenzitet primene i promene u primeni pojedinih tipova zaštite od valutnog rizika

\begin{tabular}{lcccccc}
\hline & \multicolumn{3}{c}{ Intenzitet primene } & \multicolumn{3}{c}{ Promene u primeni } \\
\cline { 2 - 7 } & $\begin{array}{c}\text { Nema } \\
\text { primene }\end{array}$ & $\begin{array}{c}\text { Sporadična } \\
\text { primena }\end{array}$ & $\begin{array}{c}\text { Stalna } \\
\text { primena }\end{array}$ & Opadaju & Ostaju iste & Rastu \\
\cline { 2 - 7 } Transakcioni & 3 & 6 & 23 & 0 & 4 & 25 \\
Translacioni & 14 & 10 & 8 & 0 & 8 & 10 \\
Operativni & 27 & 2 & 4 & 0 & 2 & 4 \\
\hline
\end{tabular}

Izvor: Autor, prema podacima iz Ankete

izloženosti sadrži i podatke koji se ne javljaju u konvencionalnim finansijskim izveštajima, a koji mogu dovesti do pozitivnih i negativnih kursnih razlika, kao što su valutni forward ugovori i ugovorene buduće prodaje i nabavke. S druge strane, ovaj izveštaj ne obuhvata stavke koje nisu direktno povezane s transakcijama u stranoj valuti (na primer, gotovinu).

Sledeći izveštaj o multivalutnoj transakcionoj izloženosti (Tabela 4) otkriva efekte promene deviznih kurseva na računovodstvene podatke filipinske filijale $\mathrm{u}$ uslovima promene vrednosti pezosa prema australijskom dolaru, indonezijskom rupiju i američkom dolaru (Choi \& Meek, 2008, 434).

Pri tome, $\mathrm{u}$ fokusu nije prva kolona koja sadrži podatke o transakcijama koje se evidentiraju i izmiruju u pezosima. Evidentno je da je devalvacija pezosa u odnosu na australijski i američki dolar, zbog pozitivne neto izloženosti $u$ obe valute, rezultirala $\mathrm{u}$ transakcionom dobitku. Istovremeno, devalvacija pezosa u odnosu na indonezijski rupi je zbog negativne izloženosti dovela do transakcionog gubitka. Na bazi ilustrovanog primera, koji, agregatno posmatrano, reflektuje odsustvo transakcione izloženosti, može se argumentovati značaj valutno dekomponovanog prikazivanja transakcione izloženosti deviznom riziku.

I pored nespornog značaja multivalutnog prikazivanja transakcione izloženosti, sprovedeno istraživanje u RS je pokazalo krajnje nezadovoljavajuće stanje. Konkretno, na pitanje da li sastavljate multivalutni

Tabela 4 Multivalutna transakciona izloženost (u 000 \$)

\begin{tabular}{lccccc}
\hline & Filipinski pezos & Australijski dolar & Indonezijski rupi & SAD dolar & Ukupno \\
\cline { 2 - 6 } Izložena sredstva & & & & & \\
Potraživanja & 45.000 & 15.000 & - & 40.000 & 100.000 \\
Zalihe & 90.000 & - & - & - & 90.000 \\
Ugov. buduće prodaje & - & 10.000 & - & - & 10.000 \\
Ukupno & 135.000 & 25.000 & & 40.000 & 200.000 \\
Izložene obaveze & & & & & \\
Kratkoročne obaveze & 20.000 & 2.500 & 12.500 & 5.000 & 40.000 \\
Ugov. dugor. krediti & 50.000 & - & - & 30.000 & 80.000 \\
Buduće nabavke & - & - & 10.000 & - & 10.000 \\
Lizing & - & 5.000 & - & - & 5.000 \\
Ukupno & 70.000 & 7.500 & 22.500 & 35.000 & 135.000 \\
Neto izloženost & & 17.500 & $(22.500)$ & 5.000 & \\
\hline
\end{tabular}

Izvor: Choi \& Meek, 2008, 434 
izveštaj o transakcionoj izloženosti deviznom riziku po valutama i zemljama, od ukupnog broja ispitanika čak $80 \%$ je dalo negativan odgovor.

U cilju zaštite od transakcione izloženosti preduzeća mogu koristiti brojne operativne tehnike (na primer, poravnanje izloženosti, usklađivanje plaćanja), koje se prevashodno koriste za zaštitu od operativnog tipa izloženosti preduzeća deviznom riziku. Kako se zaštita od transakcione izloženosti operacionalizuje prevashodno primenom valutnih finasijskih derivata, u nastavku će biti izloženi ključni aspekti finansijskog hedžinga transakcija u stranoj valuti.

\section{FINANSIJSKI HEDŽING TRANSAKCIONE IZLOŽENOSTI}

Suštinski, finansijska hedžing transakcija u stranoj valuti (Slika 1) pretpostavlja:

- postojanje deviznog rizika,

- postojanje hedžing stavke (pozicije na koju valutni rizik deluje), $\mathrm{i}$

- korišćenje hedžing instrumenta u cilju zaštite od valutnog rizika.

Svakodnevne valutne fluktuacije i porast integracije svetske privrede su glavni razlozi zbog kojih poslovni subjekti smatraju devizni rizik najvažnijim tipom

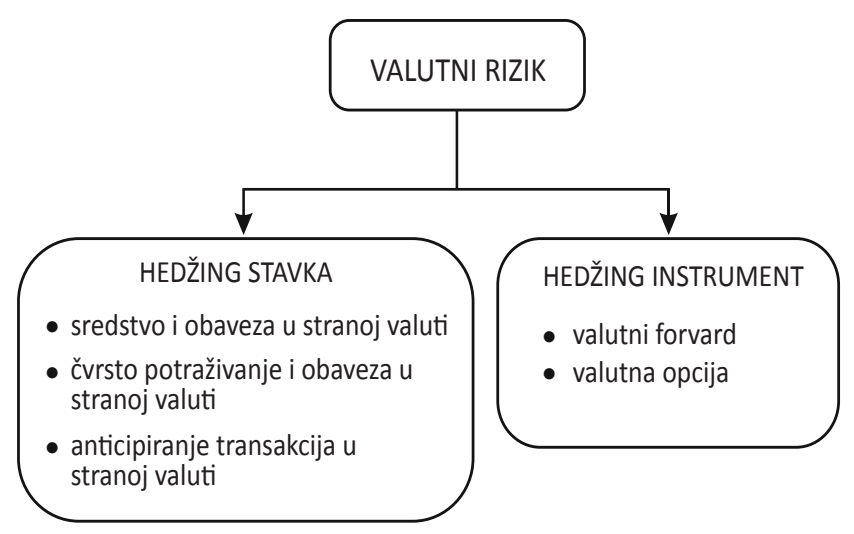

Slika 1 Pretpostavke valutnog hedžinga rizika. Fokusiranost poslovne javnosti na devizni rizik F. Choi i G. Meek $(2008,428)$ obrazlažu sledećim činjenicama: "(1) devizni rizik je najzastupljenija forma rizika s kojom se suočavaju multinacionalna preduzeća, (2) istaknuti finansijski izvršioci ističu da devizni rizik predstavlja jedan od najkompleksnijih eksternih rizika kojim se bave finansijski menadžeri i (3) može se povući paralela između koncepta upravljanja deviznim rizikom i korespondentnog računovodstvenog tretmana i ostalih vrsta tržišnih rizika."

Zbog deviznog rizika, s kojim se suočavaju pri obavljanju svojih aktivnosti, poslovni subjekti preduzimaju veliki broj hedžing mera koje su prevashodno usmerene na zaštitu od transakcione i operativne izloženosti. Hedžing predstavlja proces zaštite entiteta od izloženosti riziku stičući ili kreirajući instrumente pomoću kojih se uspostavlja protivteža datom tipu rizika. Shodno tome, valutni hedžing predstavlja povezivanje dobitaka i gubitaka na valutnim derivatima (hedžing instrumentima) sa gubicima ili dobicima na pozicijima koje su objekat valutnog hedžinga. Preduzeća ulaze $u$ hedžing aranžmane da bi minimizirala nepovoljne efekte promena deviznih kurseva na novčane tokove i neto rezultat. Računovodstvo valutnog hedžinga predstavlja „specifičan računovodstveni tretman koji, po uspostavljanju hedžinga, omogućava izjednačavanje promena vrednosti hedžing stavke i valutnog hedžing instrumenta $u$ istom periodu“ (Bierman et al, 1991, 6). Cilj računovodstva valutnog hedžinga je da se obezbedi da finansijski izveštaji entiteta koji se bave hedžing aktivnostima reflektuju rezultate ovih aktivnosti. Računovodstvo hedža se posmatra kao sredstvo pomoću koga se dovode $\mathrm{u}$ vezu efekti hedžing komponenata, odnosno, hedžing stavke i hedžing instrumenta na finansijske izveštaje, omogućavajući na taj način da se efektivnost hedžing relacije reflektuje kroz finansijske izveštaje. Propust računovodstva hedža da kroz finansijske izveštaje odrazi hedžing aktivnosti metaforički se poistovećuje s mapom koja ne prezentira relevantna geografska obeležja (Bierman et al, 1991, 6).

Stavka hedžinga, koja izlaže entitet deviznom riziku, može biti priznato sredstvo i obaveza, čvrsta transakcija, odnosno čvrsto potraživanje/obaveza, kao 
i anticipirana transakcija u stranoj valuti. Pre svega, preduzeća se suočavaju sa valutnim rizikom pri realizaciji robe na inostranom tržištu na kredit. Da bi se zaštitila od uticaja nepovoljnih promena deviznih kurseva pri naplati iznosa na ime ino-potraživanja, preduzeća veoma često koriste valutne derivate, među kojima su najzastupljeniji valutni forward-i i valutne opcije.

Korišćenje valutnog forward-a možemo ilustrovati na primeru uvozne transakcije domaćeg preduzeća. Ovo preduzeće treba da nabavi na kredit robu $\mathrm{u}$ inostranstvu koju će platiti u stranoj valuti. Zbog mogućnosti promene deviznog kursa domaće i strane valute, kao i zbog korišćenja kreditnih uslova plaćanja pri izmirenju ove transakcije, tj. obaveze $\mathrm{u}$ stranoj valuti, domaće preduzeće je izloženo deviznom riziku. U cilju njegovog eliminisanja, ili reduciranja, preduzeće može koristiti valutni forward. Shodno ovom ugovoru, preduzeće će na određeni dan u budućnosti primiti odgovarajući iznos strane valute po kursu po kojem su se danas sporazumele ugovorne strane. Kao rezultat ove derivatne transakcije nepovoljno kretanje deviznog kursa domaće i strane valute, koje uslovljava povećanje obaveze prema inodobavljaču, neutrališe se pozitivnom promenom valutnog forward ugovora. Dok je na transakciji nabavke preduzeće ostvarilo gubitak, na valutnom forward-u je ostvarilo dobitak. Drugim rečima, gubici na transakciji nabavke se anuliraju derivatnom kontratransakcijom. Fleksibilniju mogućnost hedžinga pruža valutna opcija koja imaocu daje pravo, ali ne i obavezu, da trguje stranom valutom u budućnosti.

Preduzeća koja se bave aktivnostima u stranoj valuti često ulaze $u$ hedžing aranžmane po prijemu neotkazive prodajne porudžbine ili pri ispostavljanju neotkazivog naloga za nabavku Neotkaziva porudžbina sa specificiranom cenom u stranoj valuti i datumom isporuke poznata je kao čvrsta transakcija, tj. kao čvrsto potraživanje/obaveza u stranoj valuti. I za potrebe zaštite čvrste transakcije mogu se koristiti valutni derivati. Neka preduzeća se redovno suočavaju sa transakcijama u stranoj valuti koje se mogu pouzdano predvideti. Pod takvim okolnostima preduzeće je, čak i u slučaju nepotpisivanja ugovora o budućim nabavkama, izloženo valutnom riziku. I za zaštitu tih anticipiranih transakcija u stranoj valuti mogu se koristiti valutni derivati.

Derivati koje kompanije žele da koriste za računovodstvo hedžinga moraju biti strukturisani ili za zaštitu poštene vrednosti ili za zaštitu novčanih tokova. Za potrebe zaštite priznatih sredstava $\mathrm{i}$ obaveza, kao i čvrstih transakcija u stranoj valuti kompanije moraju izvršiti izbor između ova dva tipa određenja. Za razliku od toga, zaštita anticipiranih transakcija se može kvalifikovati isključivo kao hedžing novčanih tokova. Za ova dva tipa hedža primenjuju se različiti računovodstveni postupci. Generalno, dok se dobici i gubici na hedžingu poštene vrednosti neposredno priznaju u neto dobitku, dobici i gubici na hedžingu novčanih tokova se obuhvataju u okviru Ostalog ukupnog rezultata (Fraser \& Ormiston, 2013, 132).

Upotreba derivata od strane preduzeća za potrebe zaštite od valutnog rizika je široko rasprostranjena i u porastu je. Tendencija porasta korišćenja ovih protektivnih kreacija finansijskog inženjeringa u savremenim razvijenim ekonomijama za potrebe zaštite od valutnog rizika se obrazlaže njihovom jednostavnom primenom, fleksibilnošću, niskim transakcionim troškovima, kao i realnim mogućnostima da se smanji, ili neutrališe, dejstvo ovog tipa rizika. Porast upotrebe valutnih derivata omogućava i fleksibilniji pristup u komponovanju valutno senzitivne aktive i pasive.

Istražujući prakse upravljanja deviznim rizikom $\mathrm{u}$ nefinasijskim preduzećima veliki broj autora je utvrdio postojanje pozitivne korelacije između nivoa izloženosti preduzeća deviznom riziku i stepena korišćenja finansijskih derivata (De Ceuster et al, 2000; Menon \& Viswanathan, 2005).

U nemogućnosti da se detaljno prikažu rezultati sprovedenog originalnog empirijskog istraživanja postojećeg stanja računovodstvene prakse prevođenja strane valute $i$ valutnog hedžinga $u$ preduzećima $u$ gradovima Zapadne Srbije (Dmitrović-Śaponja i ostali, 2011) u nastavku će biti fragmentarno prikazani samo oni podaci koji su relevantni za testiranje polazne hipoteze: postoji statistički značajna međuzavisnost između nivoa transakcione izloženosti preduzeća deviznom riziku i stepena primene valutnog hedžinga. 
Ova hipoteza je u direktnoj vezi sa odgovorima na pitanja o tome kako su se kretali transakciona izloženost $i$ valutni hedžing $u$ anketiranim preduzećima u Zapadnoj Srbiji u periodu od 2006. do 2010. godine.

Na pitanje: kako se kretao nivo transakcione izloženosti u preduzeću u navedenom periodu, od ukupnog broja ispitanih preduzeća $14,29 \%$ odgovorilo je da je taj obim "opao", 5,71\% "ostao isti," a čak $80,00 \%$ da je imao tendenciju porasta.

Na pitanje koje se odnosi na kretanje stepena primene valutnog hedžinga $u$ preduzeću $u$ posmatranom periodu, od ukupnog broja preduzeća $5,71 \%$ je odgovorilo da je stepen upotrebe valutnih derivata "opao," 28,57\% "ostao nepromenjen," 62,86\% "porastao je," a 2,86\% ispitanika nije dalo odgovor.

Testirana je međuzavisnost između nivoa transakcione izloženosti i stepena primene valutnog hedžinga. U cilju utvrđivanja stepena kvantitativnog slaganja između promenljive $\mathrm{H}$ - ocene odgovora na prvo pitanje i promenljive $\mathrm{Y}$ - ocene odgovora na drugo pitanje identifikovan je koeficijent proste linearne korelacije $\mathrm{R}_{\mathrm{xy}}=0,725026$.

Analiza statističke značajnosti linearne zavisnosti, odnosno nezavisnosti promenljivih, ocenjene pomoću $\mathrm{R}$, sprovodi se postupkom definisanja i testiranja nulte $i$ alternativne hipoteze.

Nulta hipoteza $\mathrm{H}_{0}: \rho=0$ znači: koeficijent proste linearne korelacije populacije $\rho$ statistički se značajno ne razlikuje od nule, tj. ne postoji linearna međuzavisnost posmatranih promenljivih.

Alternativna hipoteza $\mathrm{H}_{0}: \rho \neq 0$ znači: koeficijent proste linearne korelacije, $\rho$ statistički se značajno razlikuje od nule, $\mathrm{tj}$. postoji linearna međuzavisnost posmatranih promenljivih.

Testiranje hipoteze za uzorke koji imaju broj elementarnih jedinica veći od 30 sprovodi se pomoću standardizovanog normalnog rasporeda.

Statistika testa je $z=R_{S} \sqrt{n-1}$.

Rizik greške $\alpha=0,05$.

Test je dvosmeran. Teorijska vrednost $\mathrm{z}_{\alpha / 2}=1,96$.
Procedura zaključivanja je standardna za z-test.

Kako je na prosleđeni Upitnik odgovorilo 35 ispitanika, $\mathrm{u}$ ovom slučaju je $n=35$. Kako je $n>30$,

$$
z=0,725026 \sqrt{35-1}=4,2276 .
$$

Pošto su $|z|>z_{\alpha / 2}$ i $p<0,05$, to se prihvata alternativna hipoteza, a to znači da postoji statistički značajna linearna međuzavisnost između nivoa transakcione izloženosti i stepena primene valutnog hedžinga, čime je potvrđena polazna hipoteza.

\section{ZAKLJUČAK}

Ambiciozno postavljen okvir istraživanja računovodstvenih implikacija prevođenja i hedžinga transakcija u stranoj valuti otvorio je brojna teorijskometodološka i aplikativna pitanja. Osvetljavanjem ključnih aspekata računovodstvenog tretmana transakcija $\mathrm{u}$ stranoj valuti $\mathrm{i}$ njihovog hedžinga argumentovana je uvodom nagoveštena kompleksnost, značaj i aktuelnost razmatrane problematike.

Bilo koju transakciju čiji se uslovi regulisanja iskazuju u stranoj valuti možemo dualno posmatrati, dekomponujući je na dva tesno povezana dela: monetarni i realni. Opšte je prihvaćen stav po kojem prevođenje nemonetarnog dela transakcije, odnosno, realne aktive treba bazirati na istorijskim deviznim kursevima. Međutim, kada je reč o prevođenju monetarne aktive (potraživanja) i obaveza, nije usvojen jedinstven stav zbog suprotnosti na relaciji princip uzročnosti-princip opreznosti.

Usled uticaja fluktuacija deviznih kurseva na transakcije u stranoj valuti, preduzeća se suočavaju sa transakcionom izloženošću valutnom riziku, koja se pri regulisanju monetarnog dela transakcije efektuira na njegove novčane i tokove rentabiliteta. Konkretno, transakciona izloženost nastaje usled promene kursa razmene između perioda nastanka ino-obaveze/ potraživanja i perioda njihovog regulisanja, tj. isplate, odnosno naplate, respektivno. Drugim rečima, ukoliko u periodu između nastanka i definitivnog regulisanja transakcije u stranoj valuti dođe do promene deviznog kursa, promena vrednosti korespondentnih novčanih tokova u stranoj valuti bi dovela do pozitivnih ili 
negativnih kursnih razlika. Značaj identifikovanja nivoa transakcione izloženosti proizlazi iz činjenice da se radi o objektivno uslovljenoj izloženosti deviznom riziku usled neregulisanih ino-potraživanja i/ili inoobaveza koje su formirane pre, a izvršiće se nakon promena deviznih kurseva. Opravdana težnja uprave preduzeća da se zaštiti od dejstva transakcionog rizika operacionalizuje se prevashodno korišćenjem valutnih derivata, među kojima su najzastupljeniji valutni forward-i i valutne opcije.

Izvršenim teorijskim razmatranjima je osvetljena interaktivnost prevođenja $i$ hedžinga transakcija u stranoj valuti, a sprovedenim empirijskim istraživanjem je potvrđena ključna hipoteza $u$ radu. Pored toga, empirijskim istraživanjem je potvrđeno da preduzeća u RS nisu na najbolji način upoznata ne samo sa računovodstvenim implikacijama prevođenja strane valute, već i s mogućnostima korišćenja finansijskih derivata za potrebe zaštite od valutnog rizika. $S$ tim $\mathrm{u}$ vezi, preduzećima $\mathrm{u}$ RS se preporučuje da sprovedu edukaciju zaposlenih računovodstvenih i finansijskih kadrova, koji nisu dovoljno upućeni u problematiku računovodstvenog obuhvata efekata promene deviznih kurseva i korišćenja valutnih derivata. Angažovanjem pojedinačnih eksperata ili naučnoobrazovnih institucija treba raditi na popularizaciji primene najnovijih teorijsko-metodoloških saznanja iz oblasti računovodstva strane valute. Bankama i ostalim finansijskim organizacijama u RS se preporučuje da bolje informišu svoje postojeće i potencijalne klijente o mogućnostima primene finansijskih derivata, kao i da preduzećima pruže konsalting usluge $u$ praktičnom korišćenju valutnog hedžinga.

Pored apostrofiranja značaja dalje primene valutnih derivata, relevantan doprinos ovoga rada se ogleda i $\mathrm{u}$ isticanju zahteva za implementacijom verifikovanih međunarodnih dostignuća iz oblasti računovodstva strane valute u preduzećima u RS. Pošto aktivno učešće u globalnim poslovnim, finansijskim i investicionim tokovima pretpostavlja i međunarodnu konvergenciju nacionalnih regulativa računovodstva strane valute, velika i srednja preduzeća u RS bi, i pored pružene mogućnosti odstupanja u cilju oblikovanja finansijskog rezultata, trebalo da konzistentno slede smernice MRS 21.
Imajući u vidu dejstvo Pravilnika o izmenama i dopunama Pravilnika o Kontnom okviru i sadržini računa $u$ Kontnom okviru za privredna društva, zadruge, druga pravna lica i preduzetnike na obuhvatanje transakcija $u$ stranoj valuti i na nivo primene valutnog hedžinga, dalja istraživanja treba usmeriti na analizu uticaja regulative računovodstva strane valute na stepen zaštite transakcija $u$ stranoj valuti. U cilju prevazilaženja osnovnog ograničenja sprovedenog empirijskog ispitivanja koje se ogleda $\mathrm{u}$ nedovoljnoj veličini uzorka, narednim istaraživanjem treba obuhvatiti veći broj preduzeća. Bilo bi korisno istražiti i primedbe na aktuelnu računovodstvenu regulativu u oblasti deviznog poslovanja, s posebnim osvrtom na nekonzistentnost primene MRS 21. Buduća istraživanja treba usmeriti i na analizu efekata nekonzistentnog bilansnog prikazivanja efekata prevođenja transakcija na finansijski položaj i uspeh preduzeća.

\section{REFERENCE}

Baker, R., Lembke V., \& King, T. (2005). Advanced Financial Accounting. NY, McGraw - Hill International Edition.

Bierman, H., Johnson, T., \& Peterson, S. (1991). Hedge Accounting: An Exploratory Study of the Underlying Issues. Research Report. USA, Financial Accounting Standards Board.

Bogićević, J. (2011). Prevođenje strane valute $i$ valutni hedžing u međunarodnom računovodstvu. Neobjavljena doktorska disertacija, Ekonomski fakultet u Subotici, Univerzitet u Novom Sadu.

Choi, F. (1997). International Accounting and Finance Handbook. USA, John Wiley \& Sons.

Choi, F., \& Meek, G. (2008). International Accounting. New Jersey. Pearson Education Inc.

De Ceuster, M., Durinck, E., Laveren, E., \& Lodewyckx, J. (2000). A survey into the use of derivatives by large nonfinancial firms operating in Belgium. European Financial Management, 6(3), 301-318.

Demirag, I., \& Goddard, S. (2004). Financial Management for International Business. England: McGraw-Hill International Companies. 
Dhanani, A. (2003). Foreign exchange risk management: a case in the mining industry. The British Accounting Review, 35, 3563.

Dmitrović-Šaponja, Lj., Bogićević, J. i Jovetić, S. (2011). Empirijska analiza ekonomske izloženosti deviznom riziku preduzeća u Srbiji. Industrija, 39(4), 331-349.

Doupnik, T., \& Perera, H. (2007). International Accounting. Singapore: McGraw-Hill International Companies.

Fraser, L., \& Ormiston, A. (2013). Understanding Financial Statements. USA: Pearson Education Limited.

Kim, S., \& Kim, S. (2006). Global Corporate Finance. USA: Blackwell Publishing.

Madura, J., \& Fox, R. (2011). International Financial Management. China: South-Western Cengage Learning.

Menon, S., \& Viswanathan, K. G. (2005). Foreign currency risk management practices in U.S. multinationals. The Journal of International Business and Law, 4(1), 57-67.
Nobes, C., \& Parker, R. (2010). Comparative International Accounting. Harlow: Pearson Education Limited.

Pravilnik o izmenama $i$ dopunama Pravilnika o kontnom okviru $i$ sadržini računa u Kontnom okviru za privredna društva, zadruge, druga pravna lica i preduzetnike. Službeni glasnik Republike Srbije, broj 9/2009.

Radebaugh, L., \& Gray, S. (1997). International Accounting and Multinational Enterprises. USA: John Wiley \& Sons, Inc.

Roberts, C., Weetman, P., \& Gordon, P. (2008). International Corporate Reporting. England: Prentice Hall.

Saudagaran, S. (2004). International Accounting: A User Perspective. USA: Thomson South-Western.

Shapiro, A. (2006). Multinational Financial Management. USA: John Wiley \& Sons, Inc.

Troberg, H. P. (1987). Foreign Currency Translation: A Comparative Analysis of Approaches. Advances in International Accounting, 1, 317-356.

Jasmina Bogićević je docent na Ekonomskom fakultetu Univerziteta u Kragujevcu. Doktorirala je u oblasti računovodstva na Ekonomskom fakultetu u Subotici, Univerziteta u Novom Sadu. Ključne oblasti naučnog interesovanja i rada su specifična područja međunarodnog računovodstva i finansijsko knjigovodstvo. 


\title{
ACCOUNTING IMPLICATIONS OF FOREIGN CURRENCY TRANSACTIONS TRANSLATION AND HEDGING
}

\author{
Jasmina Bogicevic \\ Faculty of Economics, University of Kragujevac, Kragujevac, Serbia
}

\begin{abstract}
Due to the internationalization of business and frequent fluctuations in exchange rates, information about the impact of changes in exchange rates on individual companies' and multinational groups' financial position and profitability has become increasingly important. Data on the translation effects of both foreign currency transactions and foreign subsidiaries' financial statements, a company's exposure to different types of foreign exchange risks and taken currency hedging measures enable many users of accounting contents to obtain a better picture of an entity's financial position and its profitability. The key issues relate to the choice of the exchange rate to be used in accounting data translation and the financial reporting presentation of translation effects. While the effects of the foreign subsidiaries' financial statements translation can be shown in the balance sheet and the income statement, the effects of foreign currency transactions translation are incorporated in the income statement. This paper discusses the accounting aspects of the foreign currency transactions translation, an enterprise's transactional exposure to a currency risk, and the use of financial derivative instruments to hedge against foreign exchange risk.
\end{abstract}

Keywords: foreign currency transaction, transaction exposure, foreign currency financial statements, currency hedging

JEL Classification: M41, F3 